NBER WORKING PAPER SERIES

DOES FINANCIAL CONSTRAINT AFFECT SHAREHOLDER TAXES AND THE COST OF EQUITY CAPITAL?

\author{
Chongyang Chen \\ Zhonglan Dai \\ Douglas Shackelford \\ Harold Zhang \\ Working Paper 17169 \\ http://www.nber.org/papers/w17169 \\ NATIONAL BUREAU OF ECONOMIC RESEARCH \\ 1050 Massachusetts Avenue \\ Cambridge, MA 02138 \\ June 2011
}

We would like to acknowledge our appreciation to the workshop participants at the University of Frankfurt, the Max Planck Institute for Tax Law and Public Finance, and the Vienna University of Economics and Business for their helpful comments. The views expressed herein are those of the authors and do not necessarily reflect the views of the National Bureau of Economic Research.

NBER working papers are circulated for discussion and comment purposes. They have not been peerreviewed or been subject to the review by the NBER Board of Directors that accompanies official NBER publications.

(C) 2011 by Chongyang Chen, Zhonglan Dai, Douglas Shackelford, and Harold Zhang. All rights reserved. Short sections of text, not to exceed two paragraphs, may be quoted without explicit permission provided that full credit, including $(\mathcal{C}$ notice, is given to the source. 
Does Financial Constraint Affect Shareholder Taxes and the Cost of Equity Capital?

Chongyang Chen, Zhonglan Dai, Douglas Shackelford, and Harold Zhang

NBER Working Paper No. 17169

June 2011

JEL No. G12,G32,G35,H24

\begin{abstract}
$\underline{\text { ABSTRACT }}$
We show that firms with the least elastic demand for equity capital should benefit the most from reductions in shareholder taxes. Consistent with this prediction, we find that, following 1997 and 2003 cuts in U.S. individual shareholder taxes, financially constrained firms, and particularly those with disproportionate ownership by U.S. individuals, enjoyed larger reductions in their cost of equity capital than did other firms. The results are consistent with the incidence of the tax reductions falling mostly on firms with the most pressing needs for capital. Furthermore, the findings provide an explanation for the heretofore puzzling finding that, following the unprecedented 2003 reduction in dividend tax rates, non-dividend-paying firms outperformed dividend-paying firms. Not surprisingly, we find that non-dividend-paying firms are more financial constrained than dividend-paying firms are. When a firm's financial constraint and dividend choice are jointly considered, we find that the extent of financial constraint affects the change in the cost of equity capital, but whether a firm issues a dividend does not. In other words, it appears that the extant studies suffered from the omission of a correlated variation, the extent to which a firm is financially constrained.

Chongyang Chen

School of Management,

The University of Texas at Dallas

Richardson, TX 75080-3021

cchen@utdallas.edu

Zhonglan Dai

School of Management

The University of Texas at Dallas

Richardson, TX 75080-3021

zdai@utdallas.edu

Douglas Shackelford

University of North Carolina at Chapel Hill

Kenan-Flagler Business School

Campus Box 3490, McColl Building

Chapel Hill, NC 27599-3490

and NBER

doug_shack@unc.edu

Harold Zhang

University of Texas at Dallas

harold.zhang@utdallas.edu
\end{abstract}




\section{Does Financial Constraint Affect Shareholder Taxes and the Cost of Equity Capital?}

\section{Introduction}

The purpose of this paper is to determine the extent to which a firm's financial constraint affects its cost of equity capital following changes in investors' taxes. Prior studies (e.g., Dhaliwal, Krull, and Li, 2007 (hereafter, DKL), and Guenther, Jung, and Williams, 2005, among others) document that shareholder taxes decreased a firm's cost of equity capital after the 2003 reductions in shareholder taxes. However, they ignore the potential impact of cross-sectional variation in the need for external capital on that causal relation.

We address this void in the literature by hypothesizing that reductions in shareholder taxes should lower the cost of equity capital more for financially constrained firms than for other companies. The reason is that firms facing binding financial constraint have less elastic demand for external capital than other firms do and thus are forced to pay more to access that capital. Since factors that increase the cost of equity capital, such as shareholder taxes, are borne more heavily by those firms with the least elastic demand, reductions in those factors should benefit those firms more than firms with more elastic demand. Restated, since shareholder taxes increase a firm's cost of equity capital, reductions in shareholder taxes should lower the cost of equity capital more for firms with less elastic demand (i.e., financially constrained firms) than for firms with less pressing needs for capital.

We test the extent to which financial constraint matters by evaluating the two most recent changes in U.S. shareholder taxes: the Taxpayer Relief Act of 1997 (TRA) 
and the Jobs and Growth Tax Relief Reconciliation Act of 2003 (JGTRRA). ${ }^{1}$ We analyze the impact of the tax rate changes by regressing various implied (ex ante) measures of the cost of equity capital on measures of financial constraint developed in Hadlock and Pierce (2010) and assorted controls. ${ }^{2}$

Consistent with our predictions, we find that, when shareholder tax rates are cut, the more severe the financial constraint a firm experiences, the larger the reduction in its cost of equity capital. Furthermore, as expected, we find that the reduction in the cost of equity capital is larger for those financially constrained stocks that are held disproportionately by taxable individual investors, who are subject to the shareholder taxes that were reduced, than for financially constrained firms that tend to access capital from sources that were unaffected by the rate changes, such as tax-exempt institutions, tax-deferred pensions, other corporations, and foreigners.

To our knowledge, this is the first study to evaluate the impact of financial constraint on the relation between shareholder taxes and the cost of equity capital. Prior studies report that the cost of equity capital fell after shareholder tax cuts in 2003. However, we extend those studies to show that the reduction in the cost of equity capital was increasing in the inelasticity of the firm's demand for outside capital. This implies that, to the extent the rate reductions were designed to mitigate barriers to the equity markets for financially constrained firms, the shareholder tax cuts met their desired goal.

\footnotetext{
${ }^{1}$ The Taxpayer Relief Act of 1997 lowered the maximum statutory capital gains tax rate from $28 \%$ to 20\%, but left the dividend tax rate unchanged at 38.6\%. The Jobs and Growth Tax Relief Reconciliation Act of 2003 reduced the maximum statutory tax rate for capital gains from $20 \%$ to $15 \%$ and for dividends from $38.6 \%$ to $15 \%$.

${ }^{2}$ See Dhaliwal, Krull, Li, and Moser, (2005), Dhaliwal, Heitzman, and Li (2006), Hail and Leuz (2006), DKL, among others, for estimates of the cost of equity capital for firms.
} 
Companies with binding financial constraint benefited from the tax legislation more than other firms did.

Our results also shed light on a 2003 puzzle that has eluded scholars. DKL, Auerbach and Hassett (2006) and others document that JGTRRA benefited non-dividendpaying stocks more than dividend-paying stocks. This finding is surprising because JGTRRA reduced dividend tax rates by an unprecedented 23.6 percentage points, while lowering the capital gains tax rate (the only individual shareholder tax applicable to nondividend-paying stocks) by a relatively modest five percentage points. A priori, we would have expected that the benefits from the huge dividend tax rate cuts would have dominated the benefits from smaller capital gains tax rates reductions. It then follows that since the immediate benefits of the dividend tax cut would have enjoyed solely by the dividend-paying firms, the returns from dividend-paying stocks should have exceeded those from non-dividend-paying stocks. But, alas, this was not the case; in fact the opposite was observed. ${ }^{3}$

Our findings suggest that the previous studies suffer from the omission of a variable that is correlated with the decision to issue dividends, namely the extent to which a firm is financially constrained. Not surprisingly, dividend-paying firms face less financial constraint than non-dividend-paying firms. ${ }^{4}$ When we include in our regressions

\footnotetext{
${ }^{3}$ DKL describe the puzzle in the following ways, "However, we find that non-dividend paying firms experience a larger decrease in cost of equity capital than dividend paying firms, which is inconsistent with existing theory and empirical evidence. This result suggests that further work is needed to more fully explain the relation between dividend taxes and stock prices." (p.123). "However, overall the results for the dividend paying and non-dividend paying sub-samples are puzzling and suggest that further research is needed to fully understand the relation between dividend taxes and stock prices.” (p.145).

${ }^{4}$ When we segregate our sample into those paying dividends and those not paying dividends before JGTRRA, we find that $73 \%$ of the non-dividend-paying firms have above-median financial constraint, but only $27 \%$ of the dividend-paying firms are similarly constrained. Conversely, among the below-median financially constrained group, $63 \%$ are dividend-paying firms, but only $37 \%$ are non-dividend-paying firms.
} 
a categorical variable, which indicates whether a firm pays dividends, and exclude a measure of financial constraint, the coefficient on dividend policy loads in a manner that suggests non-dividend-paying firms enjoyed a larger reduction in the cost of equity capital than did dividend-paying firms following JGTRRA. However, when we add a measure of financial constraint as an explanatory variable, the dividend policy variable becomes insignificant, while the financial constraint measure is highly significant.

In other words, the benefits of the reductions in investor taxes appear to fall on financially constrained firms, which happen to be predominantly non-dividend-paying firms. Prior studies erroneously inferred that non-dividend-paying firms benefited more from JGTRRA, when actually the benefits of JGTRRA were divvied out based on financial constraint, not on dividend policy. Thus, we conclude that cross-sectional difference in the elasticity of demand for equity capital at least partially accounts for the heretofore inexplicable stock price responses.

The omission of a correlated variable does not appear limited to JGTRRA studies. In their studies of TRA, Blouin et al, 2009, Dai et al., 2008, and Lang and Shackelford, 2000, among others, segregate firms based on whether they pay dividends. They report that the benefits of the TRA cut in capital gains taxes fell disproportionately on nondividend-paying firms. They interpret this finding as evidence that TRA affected the equity markets because its capital gains tax rate reduction (recall TRA did not alter the dividend tax rate) affected all returns of non-dividend-paying stocks, but only some of the returns of dividend-paying stocks. As with JGTRRA, we find that dividend policy is significant in those TRA regressions where we exclude a measure of financial constraint, but insignificant in those where we include a measure of financial constraint. Finding that 
the degree of financial constraint matters for two different changes in shareholder taxes (and that in both cases the decision to issue dividends is irrelevant) provides compelling evidence that the elasticity of demand is an important factor in determining the incidence of changes in shareholder taxes.

The paper is organized as follows. In Section 2, we show how the cost of equity capital is affected by the firm's financial constraint when shareholder taxes change. We then hypothesize about the relative change in the cost of equity capital for firms with different degree of financial constraint. Section 3 describes the research design. Section 4 presents the findings. Concluding remarks follow.

\section{Hypothesis development}

In a perfect and complete financial market without frictions, such as taxation or asymmetric information between firms and investors, the cost of capital (which aids managers in determining their demand for capital) and the required expected stock return (which aids investors in allocating their supply of capital) should be identical in equilibrium. However, in the presence of market frictions, such as taxes, the two measures can differ.

Assuming firms are all-equity financed, Figure 1 shows the relation between the cost of equity capital and the required expected return when investment income, such as capital gains and dividends, are taxed. The horizontal axis represents the equity capital investment and the vertical axis represents the cost of equity capital for firms $\left(r_{c}\right)$ and the required expected rate of return by investors $\left(r_{r}\right)$. We model firms' demand for capital investment as a decreasing function of the cost of equity capital, i.e., $\partial D / \partial r_{c}<0$, and 
investors' supply of capital as an increasing function of required expected return by investors, i.e., $\partial S / \partial r_{r}>0$. To focus on the effect of changes in tax rate, we assume there is no asymmetric information.

To illustrate the effect of taxes on investment income, we start with no taxation of investment income. In this case, firms' demand for capital (D) and investors' supply of capital (S) intersect at point A. The equilibrium cost of capital for firms and the required expected rate of return by investors are identical, i.e., $r_{c}^{A}=r_{r}^{A}$.

Next, we introduce shareholder taxes (dividend and/or capital gains taxes) where the tax rate is denoted by $\tau$. We assume taxes are levied directly on investors and that the marginal investors are tax-sensitive. Introducing taxes makes the investors' effective supply of capital likely to shift upward (from S to S'). Assume it shifts upward until the firms' demand for capital and investors' effective supply of capital intersect at point B. At this point, the cost of equity capital paid by firms, denoted by $r_{c}^{B}$, is no longer the same as the required after-tax expected return to investors, denoted $r_{r}^{B}=(1-\tau) r_{c}^{B}$. The former is higher than the latter, and the difference is the taxes paid to the government, i.e., $\left[r_{c}^{B}-r_{r}^{B}=\tau \times r_{c}^{B}\right]$.

Now suppose taxes on investment income decline (either a reduction in capital gains taxes or dividend taxes or both), i.e., $\tau$ goes down to $\tau^{\prime}$. The investors' effective supply of capital shifts down toward the no tax case (from S' to S”), and assume firms' demand for capital and investors' supply of capital now intersect at point C. At the new equilibrium, the cost of equity capital for firms still exceeds the investors' required aftertax expected rate of return on equity investment, i.e., $r_{c}^{C}>r_{r}^{C}$. However, following the 
reduction in investment income taxes, the new equilibrium cost of equity capital for firms is lower and the equilibrium after-tax expected return for investors is higher.

Furthermore, the reduction of cost of capital is larger for firms whose demand elasticity is low (in magnitude). Figure 2 adds a second firm with lower demand elasticity whose demand for capital is labeled as D'. Suppose that before the tax cut, both firms' demand interacts with supply S' at point B. After the tax cut, when the effective supply becomes S”, the first firm moves from point B to points C (as seen in Figure 1), but the second firm moves from point B to point C'. Note that the reduction in cost of capital is larger for the second firm than for the first firm ( $r_{c}^{B}$ to $r_{c}^{C^{\prime}}$ vs. $r_{c}^{B}$ to $\left.r_{c}^{C}\right)$. This leads us to infer that, since firms facing more severe financial constraint are the ones that have lower elasticity of demand for capital, these firms will see larger reductions in the cost of equity capital, when shareholder taxes are cut, than will firms with higher elasticity of demand for capital, i.e., firms that face less financial constraint. ${ }^{5}$ This leads to the paper's hypothesis:

Hypothesis: A reduction in shareholder tax rates will decrease the cost of equity capital of severely financially constrained firms more than firms that are less financially constrained.

\footnotetext{
${ }^{5}$ Consider two extreme cases: (1) the firm is completely constrained with no access to external capital, and (2) the firm is completely unconstrained in its access to external capital. In the first case, the firm's demand elasticity for external capital is zero because a change in the cost of equity capital has no effect on the amount of capital it can raise. In the second case, the firm's demand for external capital is very elastic because it can access the external market any time and will only choose to raise external capital when the cost of equity capital is low and refrain from using external capital when the cost of capital is high. Thus, a small increase in the cost of capital may have a large impact on the amount of external capital raised by the firm, leading to a high elasticity of demand for external capital.
} 


\section{Research design}

\subsection{Research equation}

To assess whether financial constraint affects the impact of a change in shareholder taxes on a firm's cost of equity capital, we expand DKL's regression equation by adding a measure of financial constraint and several macroeconomic controls. ${ }^{6}$ The resulting regression model is:

$$
\begin{aligned}
\hat{r}_{i t}= & \alpha+\beta_{1} \text { Post }_{t}+\beta_{2} F_{i t-1}+\beta_{3} \text { Post }_{t} \times F C_{i t-1}+\beta_{4} \text { INST }_{i t-1} \\
& +\beta_{5} \text { Post }_{t} \times I N S T_{i t-1}+\gamma X_{i t}+\varphi Z_{t}+\varepsilon_{i t},
\end{aligned}
$$

where $\hat{r}_{i t}$ is the measure of estimated cost of equity capital, Post $t_{t}$ is a dummy variable

which takes a value of zero before the tax cut and one after the tax cut, $F C_{i t-1}$ is the measure for financial constraint of firm $i$ at time $t$-1, and $I N S T_{i t-1}$ measures the percentage of institutional ownership of firm $i$ at time $t-1 .^{7} X_{i t}$ represents the firm level control variables, and $Z_{t}$ represents aggregate variables to control for the overall economic

\footnotetext{
${ }^{6}$ To the extent possible, we follow DKL throughout the paper. By building off the prior literature, we enhance our ability to isolate the impact of financial constraint on the cost of equity capital when shareholder taxes change.

${ }^{7}$ To capture different tax sensitivity of investor ownership to shareholder taxes, we construct proxies for the percentage of investor ownership of a stock (individual investors and institutional investors) using data on shares outstanding and shares owned by different types of institutional investors. The data on the institutional investors' ownership are obtained from their quarterly filings with the U.S. Securities and Exchange Commission (known as Form 13F) compiled by Thomson's Financial. This control is important because the tax rate reductions in this study only apply to income that is reported on personal tax returns, i.e., dividends received and capital gains from the selling of shares held directly by individuals or held indirectly by individuals in flow-through entities, such as mutual funds, partnerships, trusts, $\mathrm{S}$ corporations, or limited liability corporations that pass dividend income to investors' personal tax returns. The rate reductions do not apply to dividend and capital gain income for shares held by tax-deferred accounts (e.g., qualified retirement plans, including pensions, IRAs and 401(k)), tax-exempt organizations, corporations, and foreigners, among other non-individual shareholders. As discussed below, we recognize that this measure is not without controversy (see Guenther and Sansing, 2006, 2010). However, we use this measure because DKL did so. By using it, rather than some other potentially superior measure, we retain the ability to identify any departures in our findings from those in DKL.
} 
activities. ${ }^{8}$ The variable of interest is the interaction term, Post $_{t} \times F C_{i t-1}$. We will interpret a negative coefficient on $\beta_{3}$ as evidence that firms with more severe financial constraint (or inelastic demand for capital) experience a larger reduction in the cost of capital than other companies do, following a reduction in shareholder taxes.

We use the same firm level controls that DKL do: the book value-to-market value ratio (in logarithm), forecasted long-term growth of earnings, the coefficient of variation of the one-year-ahead earnings per share forecast, the average cost of equity capital over the sample period for each industry using the classification by Fama and French (1997), firm size (in logarithm) in the most recent past quarter, and risk exposures to the market, the size, and the value factors measured by $\beta_{M K T}, \beta_{S M B}$, and $\beta_{H M L}$. Following DKL, we estimate these risk factor loadings using return data for the 48 months before the beginning of the calendar year. We also include the moving average daily turnover for each firm over past 250 days leading up to the end of the most recent past quarter.

In addition, since macroeconomic activities may influence firms' demand for capital and investors' supply of capital, we add macroeconomic and aggregate financial variables, such as detrended risk-free rate (Campbell and Shiller, 1988), excess market return and its volatility, industrial production growth rate, and the consumption-wealth ratio (CAY) following Lettau and Ludvigson (2001). ${ }^{9}$ In every regression, we also include quarterly dummy variables to control for possible seasonal effect.

\footnotetext{
${ }^{8}$ In the regression analysis, we use the PROC MIXED Procedure to estimate our panel model specification. Our estimation method utilizes the clustered estimate for the standard errors which allow for both crosssectional and serial correlation.

${ }^{9}$ For the risk-free rate, we use the three month Treasury bill rate from Ken French's website and stochastically detrend the variable by removing the prior twelve month average as done in Campbell and Shiller (1988). Stock market return is measured by the excess return on the value-weighted portfolio of stocks included in the CRSP database. The growth rate of the industrial production is calculated using
} 


\subsection{Cost of equity capital measure}

Following Dhaliwal el al., (2005, 2006, 2007), among others, we estimate ex ante or implied cost of equity capital using various versions of the residual income model (Ohlson, 1995, Feltham and Ohlson, 1995). Under the assumption of clean surplus accounting on a firm's earnings and book value of equity, the dividend discount model can be written as the residual income model:

$$
P_{t}=B_{t}+\sum_{i=1}^{\infty} \frac{E_{t}\left[N I_{t+i}-r_{e} B_{t+i-1}\right]}{\left(1+r_{e}\right)^{i}}
$$

where $P_{t}$ is the stock price at the end of period $t, B_{t}$ is the firm's book value at time $t$, $N I_{t+i}$ is the firm's net income for period $t+i$, and $r_{e}$ is the firm's implied cost of equity capital. $E_{t}\left[N I_{t+i}-r_{e} B_{t+i-1}\right]$ is the abnormal earnings in excess of the cost of equity on the firm's book value and thus represents the time $t$ expected value of the residual income at time $t+i$. Following DKL, we use their three different variations of the residual income model to estimate the implied cost of equity capital: Gebhardt, Lee, and Swaminathan (2001), Claus and Thomas (2001), and Gode and Mohanram (2003). The appendix reviews the computation of these three estimates.

We find that inferences are generally the same with each of the three measures. Therefore, since each estimate has its advantages and disadvantages depending on firm and time period, we use the mean of the three estimates as our primary estimate of the consumption-wealth ratio, $C A Y$, is downloaded from Martin Lettau's website. 
cost of equity capital. Using the mean should reduce any estimation noise embedded in each estimate and, thus, provide a more reliable estimate of the cost of equity capital.

\subsection{Financial constraint measure}

We estimate a firm's financial constraint based on the latest measure developed by Hadlock and Pierce (2010). ${ }^{10}$ Analyzing 1,848 firm-years from 1995 to 2004 for 356 randomly selected firms in Compustat, they use an elaborate process to classify the financial constraint for each firm-year from 1-5, where 5 represents the most financially constrained firms. They then regress their financial constraint value for each firm-year on various potential determinants of financial constraint as identified in extant papers. The result is an ordered LOGIT model with four variables deemed relevant for classification:

(a) Cash Flow: a firm's operating income plus depreciation divided by beginning-of-year book assets; (b) Leverage: book value of long term debt divided by current book assets; (c) Size: log of inflation-adjusted assets; and (d) Firm Age: the current year minus the first year that the firm has an non-missing stock price on Compustat. ${ }^{11}$

Using the estimated coefficients for the four variables and the cut points for the five classifications of financial constraint, we can estimate the probability that firm $i$ falls into each of the five groups at time $t$. We then take the predicted probability of firm $i$ falling into group 5 (i.e., the group with the most financially constrained firms) at time $t$

\footnotetext{
${ }^{10}$ Other candidates for measuring financial constraint include the Kaplan and Zingales (1997) index, which amalgamates cash flow, Tobin's Q, leverage, dividends and cash holding scaled by book value of assets and the Whited and $\mathrm{Wu}$ (2006) index, which integrates cash flow, a dividend distribution dummy, leverage, size, industry sales growth, and firm sales growth. As pointed out by Hadlock and Pierce (2010), some of determinants used in Kaplan and Zingales (1997) and Whited and Wu (2006) may be endogenously determined with the measure of financial constraint faced by a firm and sometimes have conflicting signs. Thus, they are not suitable as determinants of a firm's financial constraint measure.

${ }^{11}$ Hadlock and Pierce (2010) show that similar financial constraint classifications can be derived using only firm size and age. In Section 4.6, we replicate the empirical tests in the study using this alternative measure, and, not surprising, inferences are largely unaltered.
} 
as the measure of firm $i$ 's financial constraint at time $t$. This probability is our primary measure of financial constraint and is termed $F C_{i t}$. Specifically, we estimate the probability of financial constraint for firm $i$ at period $t$ as follows:

$$
\begin{aligned}
& F C_{i t} \equiv \operatorname{Pr}(\text { Financially Constrained }) \equiv 1-\frac{1}{1+\exp \left(\beta^{\prime} X_{i t}-C_{4}\right)} \text { and } \\
& \beta^{\prime} X_{i t}=-0.592 \times \text { Cash Flow }_{i t}+1.747 \times \text { Leverage }_{i t}-0.357 \times \text { Size }_{i t}-0.025 \times \text { Firm Age }_{i t},
\end{aligned}
$$

where $C_{4}$ is the cut point for group four (likely financial constrained) and the associated cut points for groups 1 to 4 are estimated at $-4.191,0.208,1.494$, and 1.554 , respectively. All four estimated coefficients have consistent signs and are statistically significant at $1 \%$ level. $^{12}$

Hadlock and Pierce’s (2010) financial constraint classification process supersedes its predecessors for at least two reasons. First, it uses qualitative information to categorize a firm's financial constraint status by carefully reading statements made by managers in SEC filings such as the annual letter to shareholders and the management discussion and analysis section. Second, the sampling period for Hadlock and Pierce (2010) covers both of the two changes in shareholder taxes that we examine in this study. This facilitates the use of their coefficient estimates in computing the probability of financial constraint for firms in our sample.

\subsection{Events}

DKL limit their analysis of the impact of shareholder taxes on the cost of equity capital to the latest change in the U.S. shareholder tax law (Jobs and Growth Tax Relief

\footnotetext{
${ }^{12}$ These estimates are taken from Column (4) of Table 4 in Hadlock and Pierce (2010) and we thank Joshua Pierce for providing us the cut point estimates.
} 
Reconciliation Act of 2003 or JGTRRA), which dropped the maximum, statutory tax rate on dividends from $38.6 \%$ to $15 \%$ and the maximum, statutory tax rate on realized capital gains from $20 \%$ to $15 \%$ for positions held at least 12 months. We test our hypothesis on both JGTRRA and the change in the shareholder tax law that preceded it, the Taxpayer Relief Act of 1997 (TRA), which left the dividend tax rate unchanged but reduced the maximum, statutory tax rate on realized capital gains from $28 \%$ to $20 \%$ for positions held more than 18 months.

For TRA, we use data from the first quarter of 1995 to the fourth quarter of 1998. The categorical variable Post takes a value of zero on and before 3/31/1997 and value of one on and after 7/1/1997. For JGTRRA, we use data from the first quarter of 2001 to the fourth quarter of 2004. The categorical variable Post takes a value of zero on and before 3/31/2003 and value of one on and after 7/1/2003. We exclude the "announcement" months (coincidentally April to June for both legislations) from our examination to mitigate possible transient effects arising from uncertainty about passage of the tax legislation. Results are similar if we include the transitional periods.

\section{Results}

\subsection{Descriptive statistics}

Table 1 presents the summary statistics for firm level variables. Panel A reports the mean, median, and standard deviation for the full sample from 1995Q1 to 1998Q4 for TRA and from 2001Q1 to 2004Q4 for JGTRRA. The mean (median) cost of equity capital is $9.7 \%$ (9.1\%) with a standard deviation of $4.0 \%$ for TRA and $8.9 \%$ (8.4\%) with a standard deviation of $3.4 \%$ for JGTRRA. The mean estimated probability of a firm 
facing financial constraint $(F C)$ is $4.4 \%$ with a standard deviation of $4.1 \%$ during TRA and 3.4\% with a standard deviation of 3.2\% around JGTRRA. On average, about $29 \%$ of shares owned by institutional investors during TRA and 36\% during JGTRRA. The moving average daily turnover for the past 250 days has a mean of 0.0031 (0.0041) with a standard deviation of 0.0030 (0.0052) for TRA (JGTRRA). The book-to-market value is on average higher during JGTRRA than during TRA. The average long-term growth of earnings and the dispersion of earnings forecasts are slightly lower around JGTRRA than around TRA. Not surprisingly, firms were larger in 2003 than in 1997. The mean firm exposure to the size factor declined (from 0.85 during TRA to 0.43 during JGTRRA), but the exposure to the value factor increased (from 0.15 during TRA to 0.39 during JGTRRA).

Panel B of Table 1 reports the averages for these firm level variables before and after the tax cut for both the TRA and the JGTRRA. All firm variables experienced changes in their sample means that are significant at the $10 \%$ level, except for the average exposure to the size factor under TRA. Of particular interest to this study, the estimated average cost of equity capital $\left(r_{A V E}\right)$ for both TRA and JGTRRA is lower after the tax cut than before the tax cut at the $1 \%$ level. The reduction is larger in magnitude under JGTRRA (from 0.095 to 0.083 ) than under TRA (from 0.097 to 0.096). Each of the three estimates of the cost of equity capital $\left(r_{G L S}, r_{C T}\right.$, and $\left.r_{G M}\right)$ shows similar declines. The mean probability of firms facing financial constraint is slightly lower after TRA (from $4.47 \%$ to $4.4 \%$ ), significant at $10 \%$, but more so after JGTRRA (from $3.61 \%$ to $3.04 \%$ ), significant at $1 \%$. 
Table 2 reports the summary statistics for the macroeconomic variables. The stochastically detrended monthly risk-free rate has an average of $-0.013(-0.062)$ for TRA (JGTRRA). The monthly average market excess return is 0.048 (0.016) for TRA (JGTRRA). The monthly average market return volatility is 0.035 (0.045) during TRA (JGTRRA). The monthly average industrial production growth rate is $0.008(0.001)$ for TRA (JGTRRA). The average consumption-wealth ratio is $0.014(-0.007)$ for TRA (JGTRRA). Panel B shows that the macroeconomic variables before and after the tax cuts. The statistics suggest that overall economic environment experienced more significant changes during JGTRRA than TRA.

\subsection{Univariate tests}

Table 3, Panel A reports the findings from our initial test of the hypothesis. We dichotomize the sample into high (HFC) and low (LFC) financially constrained firms and then compare their costs of capital in the quarter immediately before the tax cuts with the costs of capital in the quarter immediately afterwards. A firm is classified as having high (low) financial constraint if its probability of financial constraint in the quarter immediately preceding the tax rate cut is above (below) the median probability for all firms. For completeness, Table 3, Panel A presents the results using each of the three measures of the cost of equity capital $\left(r_{G L S}, r_{C T}\right.$, and $\left.r_{G M}\right)$, but, for brevity, we mostly limit our discussion to the average of these three measures $\left(r_{A V E}\right)$ since inferences are by and large the same for each measure.

Consistent with extant studies that report a reduction in the cost of equity capital following a reduction in shareholder taxes, we find that after TRA the average cost of 
equity capital decreased from 0.110 to 0.094 for the more financially constrained firms and from 0.087 to 0.078 for less financially constrained firm group. Following JGTRRA, the average cost of equity capital decreased from 0.099 to 0.083 for HFC companies and from 0.094 to 0.082 for LFC firms. All decreases are significant at the $1 \%$ level.

More importantly for this study, the reductions in the average cost of equity capital were larger for the firms facing a higher probability of financial constraint than for the group facing a lower probability of financial constraint. For TRA, the reduction in the average cost of equity capital is 0.0160 for the HFC firms and 0.0089 for the LFC group. The difference between the two groups is 72 basis points and significant at $1 \%$ level. For JGTRRA, the reduction is 0.0159 for the high financially constrained group and 0.0116 for the low financially constrained group, a difference of 43 basis points, which is also significant at $1 \%$ level.

Since firms facing binding financial constraint are less likely to pay dividends, we next partition the sample into dividend-paying and non-dividend-paying subsamples and repeat the difference-in-difference comparison. Table 3, Panel B presents the results.

After TRA, we find that HFC firms enjoyed a significantly larger reduction in their cost of equity capital than did LFC firms for both the dividend-paying subsample and the non-dividend-paying subsample. Furthermore, the difference-in-differences for the non-dividend-paying firms (62 basis points) exceeds the difference-in-differences for dividend-paying firms (45 basis points) and the difference is statistically significant at the $5 \%$ level.

After JGTRRA, we find that only HFC firms in the non-dividend-paying subsample enjoy a significantly larger reduction in their cost of equity capital than did 
LFC firms. The difference between HFC and LFC companies for the dividend-paying subsample is insignificant. In addition, the difference-in-differences for the non-dividendpaying firms (48 basis points) exceeds the difference-in-differences for the dividendpaying firms (10 basis points) and the difference is statistically significant at the $5 \%$ level.

To summarize, consistent with prior research, we find that the cost of equity capital fell after shareholder tax cuts. However, to our knowledge, this is the first paper to show that the decrease in the cost of equity capital varied with the firm's degree of financial constraint. Furthermore, we find that the decreases were greater for nondividend-paying firms than for dividend-paying firms, consistent with the former exhibiting lower demand for external capital. These dividend policy distinctions potentially provide at least a partial solution to the DKL puzzle about why stock prices rose more for non-dividend-paying firms than for dividend-paying firms after JGTRRA. What the extant studies identified as dividend policy distinctions may have been partially due to differences in financial constraint that were not considered, i.e., an omitted correlated variable in their analyses. We now move from univariate tests to multivariate panel regression analyses.

\subsection{Primary regression results}

Table 4 reports panel regression results from estimating equation (1). As expected, the estimated regression coefficient on the interaction term, Post $\times F C$, is negative and significant at $1 \%$ level for both TRA and JGTRRA. The results are consistent with the decline in the cost of equity capital, following a reduction in 
shareholder taxes, being greater for those firms facing the most stringent financial constraint. The estimated coefficients suggest that for a one standard deviation increase in the probability of financial constraint faced by a firm, the reduction of the cost of equity capital will be larger by 36 basis points under the TRA $(0.088 \times 0.041)$ and by 38 basis points under the JGTRRA $(0.119 \times 0.032)$.

Furthermore, including the financial constraint measures in the model reduces the coefficients on Post, leaving only the TRA one significant. The failure to find a significant coefficient on Post in the JGTRRA regression is consistent with crosssectional variation in financial constraint explaining DKL's finding that the cost of equity capital declined after JGTRRA. ${ }^{13}$

Turning to two other variables of interest, we find that the estimated regression coefficients for the variable $F C$ are positive and significant at $1 \%$, consistent with financially constrained firms facing higher costs of equity capital before the two tax cuts. This result is not surprising, but it does provide some comfort that our measure of financial constraint is capturing an important factor that increases the cost of equity capital. Likewise, we find the coefficient estimates on Post $\times I N S T$ are positive and significant at $1 \%$ for both TRA and JGTRRA, which is consistent with the finding in DKL. This result suggests that firms with higher institutional ownership experience a smaller reduction in the cost of equity capital, which is not surprising because the tax rate cuts for both TRA and JGTRRA only applied to taxable individual investors.

\footnotetext{
${ }^{13}$ When we exclude our measures of financial constraint, $F C$ and Post $\times F C$, from the regression, the coefficient on Post is negative and significantly less than zero at the $1 \%$ (5\%) level for TRA (JGTRRA).
} 


\subsection{Dividend policy－JGTRRA puzzle}

As discussed above, existing JGTRRA studies (e.g., DKL and Auerbach and Hassett, 2006) document a puzzling result: The stock prices of non-dividend-paying firms outperformed dividend-paying firms around JGTRRA, despite the fact that (a) the dividend-paying stocks benefited immediately from the reductions in both capital gains taxes and dividend taxes, while the non-dividend-paying firms only benefited from the capital gains tax cut and (b) the dividend rate reductions (23.6 percentage points) far exceeded the capital gains tax rate reductions (five percentage points).

We advance a possible explanation for this puzzle. Ceteris paribus, dividendpaying firms are less financially constrained than non-dividend-paying firms. In fact, issuing dividends is prima facie evidence that the firm has excess capital, which enables it to pay dividends. Thus, it is possible that the cost of capital response appears to vary with the decision choice because dividend policy is closely related to financial constraint. ${ }^{14}$ To test this proposition, we estimate the following specification:

\footnotetext{
${ }^{14}$ Auerbach and Hassett (2006) advance another reason why the results may not be puzzling. If managers and investors perceived that the tax cuts would be made permanent, then "immature" companies whose dividend payments lie solely in the future might have benefited more than dividend payers, which had distributed part of their profits when dividend taxes were higher. Even though the rate cuts have persisted until now, permanence would have seemed to be a risky assumption in 2003 for at least four reasons. The cuts barely passed a Republican Congress with Vice-President Cheney casting the tie-breaking vote; they were set to sunset in five years; the 2004 Democratic Presidential candidate John Kerry, who was narrowly defeated, had pledged to repeal the shareholder tax cuts, if elected, and the legislation's projected loss in tax revenues was (and remains) substantial, making it a likely prospect for subsequent tax increases. Subsequent distribution patterns provide mixed evidence about the perceptions of managers and investors. Chetty and Saez (2005) and Brown et al., (2007) report that an inordinate number of firms with large insider ownership initiated ordinary dividends soon as passage of JGTRRA, suggesting that they viewed the cuts as temporary. However, yields were low, implying they had plenty of time to distribute at the lower rates. Shackelford (2009) claims that, despite Microsoft's extraordinary 2004 special dividend of \$32 billion, few firms opted for special dividends, even though special dividends enable firms to make large distributions and avoid the expectations for continued payment associated with ordinary dividends. This may be consistent with permanence because firms forwent an opportunity to enjoy the tax benefits immediately. Blouin et al. (2011) report that dividend-paying firms increased their repurchases more than their ordinary dividends, perhaps inconsistent with permanence if these firms feared the need to recede increased ordinary dividends if rates sunset. Unable to measure market perceptions about the permanence of the rate reductions, we do not address the Auerbach and Hassett's (2006) conjecture in our tests.
} 


$$
\begin{aligned}
\hat{r}_{i t} & =\alpha+\beta_{1} \text { Post }_{t}+\beta_{2} \text { NDiv }_{i t}+\beta_{3} \text { Post }_{t} \times N D i v_{i t}+\beta_{4} F C_{i t-1}+\beta_{5} \text { Post }_{t} \times F C_{i t-1}+\beta_{6} H Y_{i t} \\
& +\beta_{7} \text { Post }_{t} \times H Y_{i t}+\beta_{8} I N S T_{i t-1}+\beta_{9} \text { Post }_{t} \times I N S T_{i t-1}+\gamma X_{i t}+\varphi Z_{t}+\varepsilon_{i t},
\end{aligned}
$$

where $N D i v_{i t}$ represents a non-dividend-paying dummy that equals one if firm $i$ does not pays dividend in quarter $t$ and zero otherwise, $H Y_{i t}$ is one if firm $i$ 's dividend yield is above the median dividend yield in that quarter and zero otherwise. ${ }^{15}$ For both TRA and JGTRRA, we estimate the model with and without the financial constraint variable to assess the effect of financial constraint on the cost of capital for firms with different dividend policy.

Although the puzzle was raised in JGTRRA work, several studies of TRA (e.g., Blouin et al., 2009, Dai et al., 2008, and Lang and Shackelford, 2000) may suffer from the same misidentification of dividend policy as a determinant of the impact of a change in shareholder taxes. These studies find that, after the TRA cut in capital gains tax rates, the equity markets responded more strongly for non-dividend-paying firms than for dividend-paying firms. These findings are interpreted as evidence that the tax cut mattered because all returns for non-dividend-paying firms were affected by the capital gains tax rate reduction, while some returns of the dividend-paying firms remained subject to the unchanged dividend tax rate. However, if the decision to issue dividends is actually a proxy for financial constraint, then these studies may have misestimated the impact of TRA, in particular, understating its effect of TRA for financially constrained, dividend-paying firms and overstating its effect on less constrained, non-dividend-paying firms.

\footnotetext{
${ }^{15}$ We include $H Y_{i t}$ as a control variable because both DKL and Auerbach and Hassett (2006) document that the impact of JGTRRA on the cost of capital for dividend-paying firms is increasing in their dividend yield. This is not surprising since the large dividend tax cut should expect benefit high-yield firms more than lowyield firms. Including a categorical variable for yield enables us to compare those firms that issue dividends with those that do not, conditional on the known variation among dividend-paying firms.
} 
Table 5 presents findings that are consistent with prior TRA and JGTRRA studies misidentifying variation in financial constraint as differences in dividend policy. We find that when the financial constraint variable is excluded, non-dividend paying firms experience a larger reduction in the cost of capital than dividend-paying firms (as indicated by the significant negative coefficient for Post $\times$ NDiv) for both TRA and JGTRRA. However, after controlling for financial constraint, non-dividend paying firms no longer experience a larger reduction in the cost of capital than dividend-paying firms (as indicated by the insignificant coefficient for Post $\times N D i v$ ). Meanwhile, the coefficient on Post $\times F C$ is negative and significant at the $1 \%$ level, consistent with the cost of capital moving inversely with financial constraint. These findings suggest that the prior studies, which report that changes in shareholder taxes vary with whether a firm pays dividends, suffer from an omitted, correlated variable, which is the extent to which a firm faces financial constraint. In other words, financial constraint matters, not the decision to pay dividends.

As noted above, we control for dividend yield because both DKL and Auerbach and Hassett (2006) report that firms with high dividend yield outperformed firms with low dividend yield. Consistent with their findings, we find that the coefficient on Post $\times H Y$ is negative and significant at the $1 \%$ level in the JGTRRA test, both when we include and exclude our measures of financial constraint. This implies that the added benefits from the dividend tax cuts for high-yield issuers overwhelmed differences, if any, in the inelasticity of demand for capital among dividend issuers. 


\subsection{Tax status of shareholders}

Next, we look at differences in the taxable status of a firm's shareholders. As mentioned above, TRA and JGTRRA only apply to returns that are reported on personal tax returns. While controversy remains about whether the marginal investor is a taxable investor, numerous empirical studies document that investor tax characteristics affect asset returns and trading volume. ${ }^{16}$ If the marginal investor is not an American individual subject to capital gains taxation, then individual shareholder tax cuts should have no direct effect on the cost of equity capital even for firms facing financial constraint. Consistent with the marginal investor being an American individual, DKL show that firms with higher tax sensitive investor ownership enjoyed a larger reduction in their cost of capital during JGTRRA.

We extend their analysis to see whether the impact of financial constraint varied with the tax sensitivity of investor ownership for both TRA and JGTRRA, in particular, whether the reduction in the cost of equity capital is larger for financially constrained stocks with higher tax sensitivity. We use the following empirical specification to test the effect of tax sensitivity on the changes in the cost of equity capital of firms facing different probability of financial constraint:

\footnotetext{
${ }^{16}$ A host of empirical papers, besides DKL, finds that the extent of institutional ownership (measured in various ways) is a useful proxy for the probability that the marginal investor is tax-advantaged. For examples, see Sias and Starks (1997), Gompers and Metrick (2001), Ayers et al., (2002, 2003), Blouin et al., (2003, 2011), Jin (2006), Dhaliwal and Li (2006), and Dai et al., (2008), among others. Nonetheless, this measure is not without controversy. In an equilibrium model, Guenther and Sansing (2006) show that the dividend tax premium should not vary with the mix of taxable and tax-exempt investors. Guenther and Sansing (2010) report that the percentage of shares held by tax-exempt investors captures factors other than differences in taxation, including differences in the relative risk tolerance of taxable investors, the riskiness of each stock, and the stock's dividend yield. We follow prior studies in using a stock's institutional ownership to measure its shareholders' sensitivity to individual taxes. We trust that the deleterious effects of any measurement error are mitigated since we only use institutional holdings to split the sample in half and do not demand additional precision from the measure.
} 


$$
\begin{aligned}
\hat{r}_{i t}= & \alpha+\beta_{1} \text { Post }_{t}+\beta_{2} \text { HIND }_{i t} \times L F C_{i t}+\beta_{3} \text { LIND }_{i t} \times H F C_{i t}+\beta_{4} H_{I N D_{i t} \times H F C_{i t}} \\
& +\beta_{5} \text { Post }_{t} \times H I N D_{i t} \times L F C_{i t}+\beta_{6} \text { Post }_{t} \times L I N D_{i t} \times H F C_{i t} \\
& +\beta_{7} \text { Post }_{t} \times H I N D_{i t} \times H F C_{i t}+\gamma X_{i t}+\varphi Z_{t}+\varepsilon_{i t},
\end{aligned}
$$

where $\operatorname{HIND}_{i t}\left(\operatorname{LIND}_{i t}\right)$ is a dummy variable which takes a value of 1 if firm $i$ 's individual investor ownership at time period $t$ is above (below) the median individual investor ownership for all firms in period $t$. If the reduction in the cost of equity capital for more financially constrained firms is larger for high tax sensitive investor ownership than for low tax sensitive investor ownership, then the coefficient on Post $\times H I N D \times H F C$ should be more negative than the coefficient on Post $\times L I N D \times H F C$.

Table 6 presents the results of our panel regression analysis. Consistent with $H F C$ firms experiencing greater reductions in their cost of equity capital, the coefficients for both $P o s t \times H I N D \times H F C$ and $P o s t \times L I N D \times H F C$ are negative and significant at $1 \%$ level under both TRA and JGTRRA. We also find that the coefficients on Post $\times H I N D \times H F C$ are more negative than the coefficients on Post $\times L I N D \times H F C$ and significantly less at the $10 \%$ level for JGTRRA. These findings are consistent with the tax-driven reductions in the cost of equity capital varying both with the level of financial constraint and with the level of individual investor ownership. In other words, the firms whose cost of equity market was reduced the most by the shareholder tax cuts were financially constrained firms held disproportionately by individual U.S. investors.

\subsection{Alternative measure of financial constraint}

Finally, we check whether the results in this study are robust to an alternative estimate of the probability of financial constraint faced by firms. As discussed above, 
several methods for measuring financial constraint exist. The tests detailed above use the latest Hadlock and Pierce (2010) measure based on leverage, cash flow, size and age. Hadlock and Pierce (2010) also suggest a measure based solely on firm size and age, arguing that leverage and cash flow may be endogenous. Specifically, after extensive empirical investigation, they arrive at the following ordered LOGIT specification which allows us to compute the probability of financial constraint for firm $i$ at period $t$ :

$$
\begin{aligned}
& \text { SA Index }{ }_{i t}=\operatorname{Pr}(\text { Financially Constrained })=1-\frac{1}{1+\exp \left(\beta^{\prime} X_{i t}-C_{4}\right)} \text { and } \\
& \beta^{\prime} X_{i t}=-0.737 \times \text { Size }_{i t}+0.043 \times \text { Size }_{i t}^{2}-0.04 \times \text { Firm Age }_{i t} \text {, }
\end{aligned}
$$

where $S A$ Index $_{i t}$ refers to the probability of financial constraint that only uses firm size and age, and $C_{4}$ is the cumulative cut point for group four (likely financially constrained). We estimated the average firms' probability of financial constraint is 0.042 with a standard deviation of 0.037 during TRA and is 0.032 with a standard deviation of 0.029 for the period surrounding JGTRRA. Both are comparable to the estimates obtained from using four variables (cash flow, leverage, size, and age) on the specification of equation (3).

Using this alternative measure of financial constraint we repeat all of the tests discussed above. Results are qualitatively the same with one exception detailed below. In general, we continue to find strong evidence that a firm's financial constraint is an important determinant of the impact of shareholder tax changes on its cost of equity capital.

The first two columns in Table 7 present the results from estimating equation (1) with the alternative measure of financial constraint ( $S A$ Index). The coefficients on Post $\times$ SA Index are negative and highly significant, indicating that, after passage of the 
tax cuts, the benefits of the shareholder tax rate reductions were increasing in the firm's inelasticity of demand, as measured with Hadlock and Pierce's (2010) alternative approach. The middle two columns present the results from estimating equation (4) with the alternative measure. Here, the findings are mixed. As with the original financial constraint measure, the JGTRRA results in column 4 show that it was the financially constrained firms that enjoyed a drop in the cost of capital following enactment, not the non-dividend-paying firms, as prior studies had suggested. Conversely, the TRA results in column 3 differ from the original findings. The coefficient on Post $\times S A$ Index is insignificant, while the coefficient on Post $\times N D i v$ is significant at $10 \%$, raising doubts about whether the inferences drawn above about financial constraint and dividend policy apply to TRA. Finally, the last two columns present the findings from estimating equation (5) with the alternative financial constraint measure. Once again, we find that the coefficients on Post $\times H I N D \times H F C$ are more negative than the coefficients on Post $\times L I N D \times H F C$ at $5 \%$ level for both TRA and JGTRRA, consistent with the incidence of the tax reduction falling on financially constrained companies held disproportionately by U.S. individuals. Together, these results show that the inferences drawn earlier in the paper are largely robust to this alternative specification of the financial constraint measure.

\section{Conclusions}

We provide the first empirical investigation of the effects of financial constraint on the impact of shareholder taxes on a firm's cost of equity capital. Theory suggests that reductions in shareholder taxes should decrease the cost of equity capital. This reduction 
should be larger for firms with more inelastic demand for capital, i.e., firms facing more severe financial constraint. Consistent with these predictions, we find that financially constrained firms, and particularly those held disproportionately by U.S. individuals, experienced a larger decrease in their cost of equity capital than did other companies following enactment of the 1997 and 2003 shareholder tax rate reductions. Consequently, to the extent that those tax cuts were designed to enable firms with the most pressing needs for equity to better access the external capital markets, the findings in this paper would suggest that the legislations succeeded.

The findings in this paper also shed light on a puzzle that has eluded researchers to date. During the JGTRRA legislative deliberations, the share prices of non-dividendpaying firms outperformed those of dividend-paying firms even though the legislation slashed dividend tax rates by 23.6 percentage points compared with a relatively modest 5 percentage point cut in capital gains tax rates. We find that the prior studies suffer from the omission of a variable that is correlated with the decision to issue dividends, namely the extent to which firms are financially constrained. When we include measures of both dividend status and financial constraint in the regression model, we find that the prior significance on the dividend variable goes away, while the financial constraint measure is highly significant. Thus, the puzzle appears at least partially solved. Non-dividendpaying firms did not benefit disproportionately from the 2003 tax rate reductions. Rather, it was the financially constrained firms (many of which do not issue dividends) that benefited the most. 


\section{References}

Altman, E., 2000, Financial ratios, discriminant analysis and the prediction of corporate bankruptcy, Journal of Finance 23, 589-609.

Ayers, B.C., Cloyd, C.B., Robinson, J.R., 2002, The effect of shareholder-level dividend taxes on stock prices: Evidence from the Revenue Reconciliation Act of 1993, Accounting Review 77, 933-947.

Ayers, B.C., Lefanowicz, C.E., Robinson, J.R., 2003, Shareholder taxes in acquisition premiums: The effect of capital gains taxation, Journal of Finance LVIII, 2783-2801.

Auerbach, A.J. and K.A. Hassett, 2006, The 2003 dividend tax cuts and the value of the firm: an event study. In: Auerbach, A., Slemrod, J. (Eds.), Taxing Corporate Income in the $21^{\text {st }}$ Century. Cambridge University Press, Cambridge.

Blouin, J., Hail, L., Yetman, M., 2009, Capital gains taxes, pricing spreads and arbitrage: Evidence from U.S. cross-listed firms, The Accounting Review,1321-1361.

Blouin, J.L., Raedy, J.S., Shackelford, D.A., 2003, Capital gains taxes and equity trading: Empirical evidence, Journal of Accounting Research 41, 611-651.

Blouin, J.L., Raedy, J.S., Shackelford, D.A., 2011, Dividends, share repurchases, and tax clienteles: Evidence from the 2003 reductions in shareholder taxes, Accounting Review 86, forthcoming.

Brown, J., Liang, N., Weisbenner, S., 2007, Executive financial incentives and payout policy: Firm responses to the 2003 dividend tax cut, Journal of Finance 62, 1035-1965.

Campbell, J. and R. Shiller, 1988, The dividend-price ratio and expectations of future dividends and discount factors, Review of Financial Studies 1, 195-227.

Chetty, R. and E. Saez, 2005, Dividend taxes and corporate behavior: evidence from the 2003 dividend tax cut, Quarterly Journal of Economics 120, 791-833.

Claus, J. and J. Thomas, 2001, Equity premia as low as three percent? Empirical evidence from analysts' earnings forecasts for domestic and international stock markets, Journal of Finance 56, 1629-1666.

Dai, Z., E. Maydew, D. Shackelford, H. Zhang, 2008, Capital gains taxes and asset prices: Capitalization or lock-in? Journal of Finance 63, 709-742.

Dhaliwal, D., S. Heitzman, and O. Li, 2006, Taxes, leverage, and the cost of equity capital, Journal of Accounting Research 44, 2006, 691-723. 
Dhaliwal, D., L. Krull, and O. Li, 2007, Did the 2003 tax act reduce the cost of equity capital? Journal of Accounting and Economics 43, 121-150.

Dhaliwal, D., L. Krull, O. Li, and W. Moser, 2005, Dividend taxes and implied cost of equity capital, Journal of Accounting Research, 675-708.

Fama, E. and K. French, 1997, Industry cost of equity, Journal of Financial Economics 43, 153-193.

Fee, E., C. Hadlock, and J. Pierce, 2009, Investment, financing constraints, and internal capital markets: Evidence from the advertising expenditures of multinational firms, Review of Financial Studies 22, 2361-2392.

Feltham, G. and J. Ohlson, 1995, Valuation and clean surplus accounting for operating and financial activities, Contemporary Accounting Research 11, 689-731.

Gebhardt, W., C. Lee, and B. Swaminathan, 2001,Toward an implied cost of equity, Journal of Accounting Research 39, 135-176.

Gode, D. and P. Mohanram, 2003, Inferring the cost of equity using the Ohlson-Juettner Model, Review of Accounting Studies 8, 399-431.

Gompers, P. and A. Metrick, 2001, Institutional investors and equity prices, Quarterly Journal of Economics 116, 229-259.

Graham, J., 1999, Do personal taxes affect corporate financing decisions? Journal of Public Economics 73, 147-185.

Guenther, D., B. Jung, and M. Williams, 2005, The effect of the 2003 dividend tax rate reduction on corporations' cost of equity capital, working paper.

Guenther, D., and R. Sansing, 2006, Fundamentals of shareholder tax capitalization, Journal of Accounting and Economics 42: 371-384.

Hail, L. and C. Leuz, 2006, International differences in cost of equity: Do legal institutions and securities regulation matter? Journal of Accounting Research 44, 485531.

Hadlock, C. and J. Pierce, 2010, New evidence on measuring financial constraints: Moving beyond the KZ index, Review of Financial Studies 23, 1909-1940.

Jin, L., 2006, Capital gain tax overhang and price pressure." Journal of Finance 61, 1399-1430.

Kaplan, S. and L. Zingales, 1997, Do investment-cash flow sensitivities are not valid measures of financial constraints, Quarterly Journal of Economics 112, 159-216. 
Lang, M., and D. Shackelford, 2000, Capitalization of capital gains taxes: evidence from stock price reactions to the 1997 rate reduction, Journal of Public Economics 76, 69-85.

Lettau, M. and S. Ludvigson, 2001, Consumption, aggregate wealth and expected stock returns, Journal of Finance 56, 815-849.

Litzenberger, R. and K. Ramaswamy, 1979, The effect of personal taxes and dividends on capital asset prices: Theory and evidence, Journal of Financial Economics 7, 163-196.

Naranjo, A., M. Nimalendran, and M. Ryngaert, 1998, Stock returns, dividend yields, and taxes, Journal of Finance 53, 2029-2057.

Ohlson, J., 1995, Earnings, book value, and dividends in security valuation, Contemporary Accounting Research 11, 661-687.

Rauh, J., 2006, Investment and financing constraints: Evidence from the funding of corporate pension plans, Journal of Finance 61, 33-72.

Shackelford, D., 2009, Chapter 10: A response to Dhammika Dharmapala, Tax Policy Lessons from the 2000's, AEI Press, 232-245.

Sias, R. and L. Starks, 1997, Return autocorrelation and institutional investors, Journal of Financial Economics 46, 103-131.

Whited, T. and G. Wu, 2006, Financial constraints risk, Review of Financial Studies 19, 531-559. 


\section{Appendix}

This appendix reviews the computations of the three estimates of a firm's implied cost of equity capital used in this study:

\section{A. Gebhardt, Lee, and Swaminathan Model (GLS)}

Gebhardt, Lee, and Swaminathan (2001) use the following equation to estimate a firm's implied cost of equity:

$$
P_{t}=B_{t}+\frac{F R O E_{t+1}-r_{e}}{\left(1+r_{e}\right)} B_{t}+\frac{F R O E_{t+2}-r_{e}}{\left(1+r_{e}\right)^{2}} B_{t+1}+T V,
$$

where $B_{t}$ is the firm's per share book value at the beginning of time $t, F R O E_{t+i}$ is forecasted return on equity (ROE) for period $t+i$, i.e., $F R O E_{t+i}=F E P S_{t+i} / B_{t+i-1}, i=1,2$, and $F E P S_{t+i}$ is the $\mathrm{I} / \mathrm{B} / \mathrm{E} / \mathrm{S} 1$ - and 2- year-ahead earnings per share forecast, $T V$ is the terminal value calculated according to

$$
T V=\sum_{i=3}^{T-1} \frac{F R O E_{t+i}-r_{e}}{\left(1+r_{e}\right)^{i}} B_{t+i-1}+\frac{F R O E_{t+T}-r_{e}}{\left(1+r_{e}\right)^{T-1}} B_{t+T-1},
$$

where the forecasted ROE for period $t+3$ is calculated using the $\mathrm{I} / \mathrm{B} / \mathrm{E} / \mathrm{S}$ analyst 2-yearahead earnings per share forecast multiplied by the $\mathrm{I} / \mathrm{B} / \mathrm{E} / \mathrm{S}$ analysts' consensus long-term growth rate, the forecasted ROE for periods beyond $t+3$ is calculated using the linear interpolation procedure to the industry median ROE proposed by GLS, $B_{t+i}$ is calculated according to the clean surplus accounting as $B_{t+i-1}+F E P S_{t+i}-F D P S_{t+i}$, where $F D P S_{t+i}$ is forecasted dividends per share, which is equal to forecasted earnings per share for period $t+i$ multiplied by the year $t$ dividend payout ratio. Following GLS and Dhaliwal, et al (2005, 2006, and 2007), we calculate the implied cost of equity capital for $T=12$. 


\section{B. Claus and Thomas Model (CT)}

Claus and Thomas (2001) use the following equation to estimate the implied cost of equity capital:

$$
P_{t}=B_{t}+\frac{A E_{t+1}}{\left(1+r_{e}\right)}+\frac{A E_{t+2}}{\left(1+r_{e}\right)^{2}}+\frac{A E_{t+3}}{\left(1+r_{e}\right)^{3}}+\frac{A E_{t+4}}{\left(1+r_{e}\right)^{4}}+\frac{A E_{t+5}}{\left(1+r_{e}\right)^{5}}+\frac{A E_{t+5}\left(1+g_{a e}\right)}{\left(r_{e}-g_{a e}\right)\left(1+r_{e}\right)^{5}},
$$

where $A E_{t+i}=F E P S_{t+i}-r_{e} B_{t+i-1}$ is the expected abnormal earnings for period $t+i$. Following Dhaliwal, et al (2005, 2006, and 2007), when I/B/E/S earnings forecast is unavailable, we use FEPS for the prior year multiplied by one plus the $\mathrm{I} / \mathrm{B} / \mathrm{E} / \mathrm{S}$ consensus long-term growth forecast, $g_{a e}$ is the growth rate of abnormal earnings beyond period $t+5$ and is set to equal to the yield on 10 -year U.S. treasury bonds minus three percentage points as in DKL.

\section{Gode and Mohanram Model (GM)}

Gode and Mohanram (2003) use the following formula to estimate the cost of equity capital:

$$
r_{e}=A+\sqrt{A^{2}+\left(\frac{F E P S_{t+1}}{P_{t}}\right)\left[g_{2}-\left(r_{f}-0.03\right)\right]},
$$

where $A=\left[\left(r_{f}-0.03\right)+F D P S_{t+1} / P_{t}\right] / 2$ and $g_{2}$ is set equal to the $\mathrm{I} / \mathrm{B} / \mathrm{E} / \mathrm{S}$ consensus long-term growth forecast when available and equal to $\left(F E P S_{t+2} / F E P S_{t+1}-1\right)$ when the consensus growth forecast is unavailable, $F D P S_{t+1}$ is the forecasted per share dividends calculated as forecasted per share earnings at time $t+1$ multiplied by dividend payout ratio at time $t, r_{f}$ is set to equal to the yield on 10-year U.S. treasury bonds. 


\section{Figure 1}

\section{Cost of Equity Capital and Shareholder Taxes}

This figure illustrates the effect of shareholder tax rate change on the firm's cost of capital. Without shareholder taxation, in equilibrium, the cost of capital and the required return are identical, i.e. $r_{c}^{A}=r_{r}^{A}$ (equilibrium point A). With shareholder taxation, $r_{r}^{B}<r_{c}^{B}$ (equilibrium point $\mathrm{B}$ ) due to the tax wedge. As the shareholder taxation is reduced (equilibrium point $\mathrm{C}$ ), the cost of capital for firms is lower $\left(r_{c}^{C}<r_{c}^{B}\right)$ and the required expected return is higher $\left(r_{r}^{C}>r_{r}^{B}\right)$.

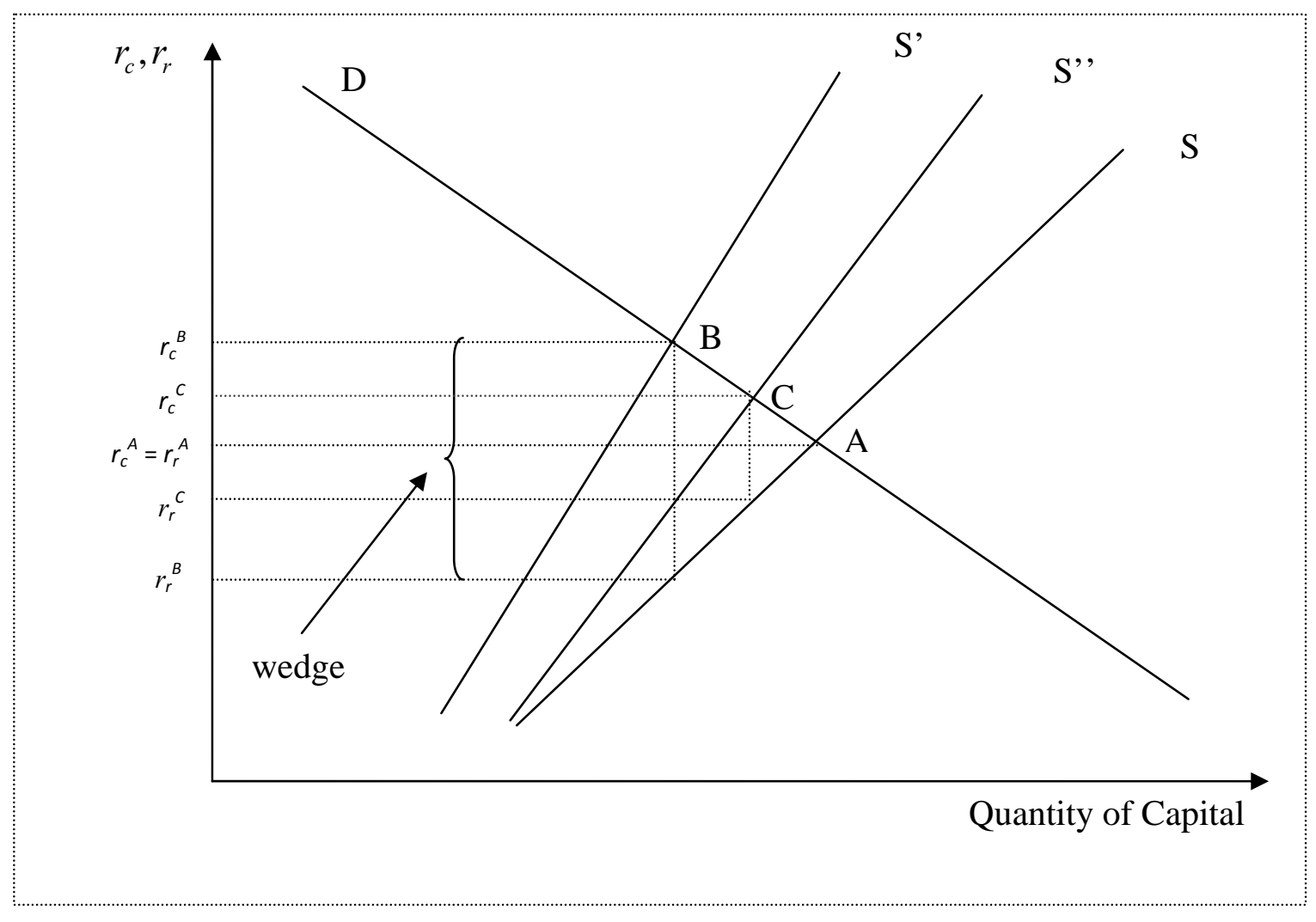


Figure 2

\section{Cost of Equity Capital and Shareholder Taxes for Different Firms}

This figure illustrates the effect of a shareholder tax rate change on the cost of capital for firms with different demand elasticity. Suppose the second firm with less elastic demand for capital (labeled as D') also has equilibrium at point B before the tax cut. The new equilibrium after the tax cut will be at point $C^{\prime}$ for this second firm and $C$ for the first firm. The drop of cost of capital would be larger for the second firm (from $r_{c}^{B}$ to $r_{c}^{C^{\prime}}$ ) than for the first firm (from $r_{c}^{B}$ to $r_{c}^{C}$ ).

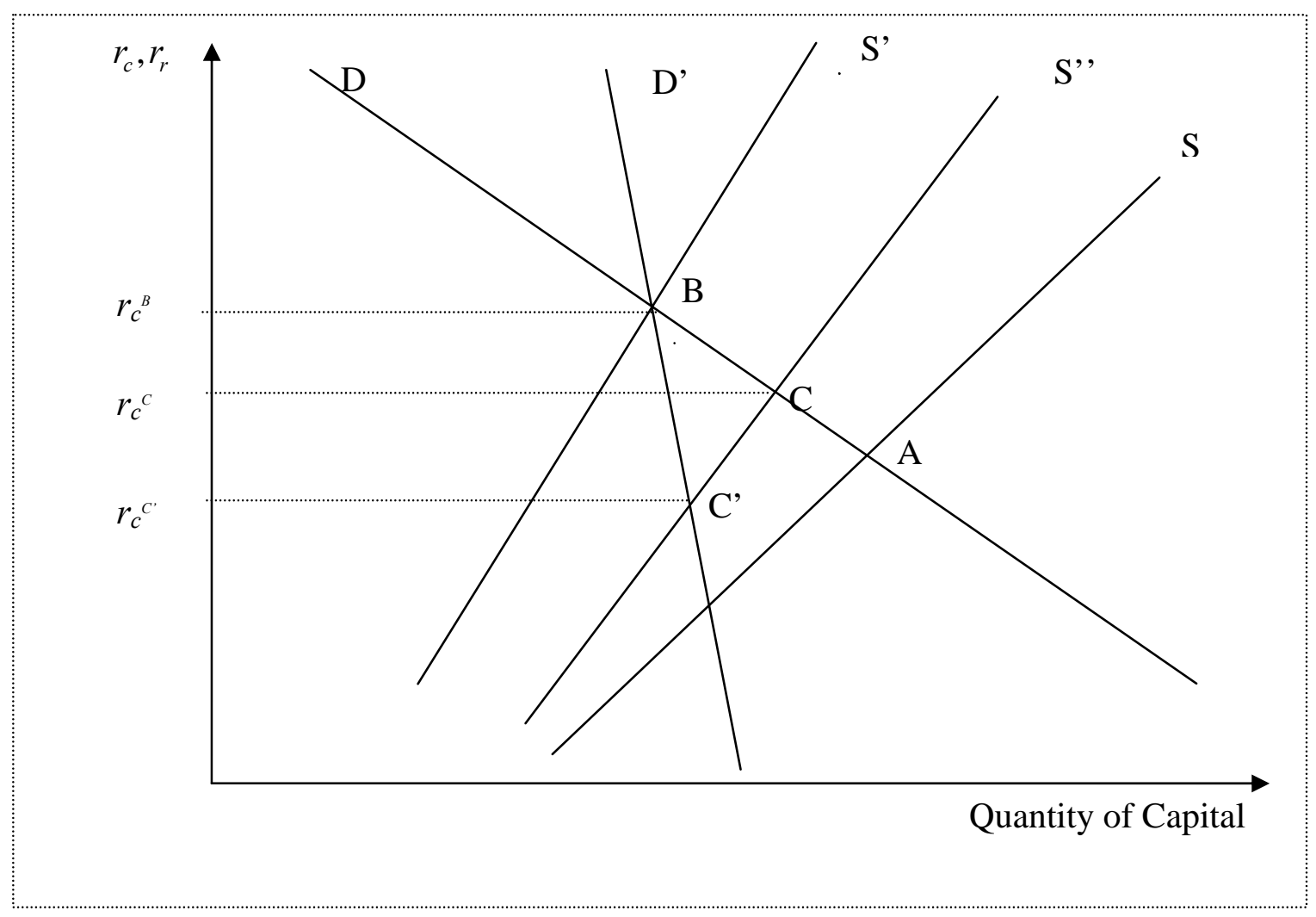


Table 1 Summary statistics - firm level variables

This table reposts summary statistics for firm characteristics for the period surrounding TRA and JGTRRA for the full sample (Panel A) and the pre- and post- subsamples (Panel B). $r_{G L S}, r_{C T}, r_{G M}$ and $r_{A V E}$ are the cost of capital estimated using methods by Gebhardt, Lee, and Swaminathan (2001), Claus and Thomas (2001), and Gode and Mohanram (2003) and the average of the above three respectively; $F C$ is the predicted probability of a firm being financially constrained in quarter t using Hadlock and Pierce (2010) method; INST is the percentage ownership by institutional investors; Turnover is the moving average of the past 250 daily volume scaled by the shares outstanding; $\log B M$ is the logarithm of the book-to-market ratio; $\log L T G$ is the logarithm of the forecasted long-term earnings growth rate; LogDisp is the logarithm of the dispersion of the forecasted long-term growth rate; $r_{i}$ is the industry average cost of capital for 48 industries classified according to Fama and French (1997); LogSize is the logarithm of a firm's market capitalization; $\beta_{m k t}, \beta_{s m b}$, and $\beta_{h m l}$ are the beta coefficient relative to the market, the SMB, and the HML factor, respectively. The sample spans 1995Q1 to 1998Q4 for TRA and 2001Q1 to 2004Q4 for JGTRRA.

Panel A: full sample

\begin{tabular}{|c|c|c|c|c|c|c|}
\hline & \multicolumn{3}{|c|}{ TRA } & \multicolumn{3}{|c|}{ JGTRRA } \\
\hline & Mean & Median & Std Dev & Mean & Median & Std Dev \\
\hline$r_{A V E}$ & 0.0966 & 0.0907 & 0.0402 & 0.0893 & 0.0837 & 0.0344 \\
\hline$r_{G L S}$ & 0.0843 & 0.0827 & 0.0343 & 0.0839 & 0.0811 & 0.0324 \\
\hline$r_{C T}$ & 0.1014 & 0.0904 & 0.0634 & 0.0895 & 0.0796 & 0.0555 \\
\hline$r_{G M}$ & 0.1047 & 0.0985 & 0.0430 & 0.0947 & 0.0901 & 0.0380 \\
\hline$F C$ & 0.0444 & 0.0330 & 0.0412 & 0.0340 & 0.0251 & 0.0316 \\
\hline Yield & 0.0199 & 0.0000 & 0.0341 & 0.0228 & 0.0037 & 0.0370 \\
\hline INST & 0.2866 & 0.2219 & 0.2466 & 0.3561 & 0.2988 & 0.2924 \\
\hline Turnover & 0.0031 & 0.0022 & 0.0030 & 0.0041 & 0.0024 & 0.0052 \\
\hline $\log B M$ & -0.6719 & -0.6568 & 1.0248 & -0.3687 & -0.4934 & 1.2377 \\
\hline $\log L T G$ & 2.8625 & 2.8261 & 0.6514 & 2.7703 & 2.7081 & 0.6525 \\
\hline LogDisp & -3.0820 & -3.2387 & 1.1467 & -3.2613 & -3.4340 & 1.2503 \\
\hline$r_{i}$ & 0.0964 & 0.0958 & 0.0110 & 0.0904 & 0.0892 & 0.0117 \\
\hline LogSize & 4.7829 & 4.6593 & 1.8613 & 5.2070 & 5.1185 & 2.0293 \\
\hline$\beta_{m k t}$ & 0.9360 & 0.8615 & 1.1688 & 0.9902 & 0.8818 & 0.9157 \\
\hline$\beta_{s m b}$ & 0.8499 & 0.6468 & 1.5019 & 0.6052 & 0.4275 & 0.9202 \\
\hline$\beta_{h m l}$ & 0.1473 & 0.2838 & 1.7991 & 0.1926 & 0.3857 & 1.1876 \\
\hline
\end{tabular}


Panel B: pre-vs. post

\begin{tabular}{lrrrrrr}
\hline & & \multicolumn{2}{c}{ TRA } & & JGTRRA & \\
& Pre & Post & Pr(diff=0) & Pre & Post & $\operatorname{Pr}($ diff=0) \\
\hline$r_{A V E}$ & & & & & & \\
$r_{G L S}$ & 0.0974 & 0.0956 & $<.0001$ & 0.0945 & 0.0827 & $<.0001$ \\
$r_{C T}$ & 0.0848 & 0.0837 & $<.0001$ & 0.0882 & 0.0780 & $<.0001$ \\
$r_{G M}$ & 0.1025 & 0.0999 & $<.0001$ & 0.0963 & 0.0805 & $<.0001$ \\
FC & 0.1054 & 0.1038 & $<.0001$ & 0.0995 & 0.0886 & $<.0001$ \\
Yield & 0.0447 & 0.0440 & 0.0843 & 0.0361 & 0.0304 & $<.0001$ \\
INST & 0.0208 & 0.0187 & $<.0001$ & 0.0234 & 0.0218 & 0.0015 \\
Turnover & 0.2800 & 0.2961 & $<.0001$ & 0.3345 & 0.3919 & $<.0001$ \\
LogBM & 0.0030 & 0.0032 & $<.0001$ & 0.0038 & 0.0047 & $<.0001$ \\
LogLTG & -0.6644 & -0.6826 & $<.0001$ & -0.2198 & -0.6167 & $<.0001$ \\
LogDisp & 2.8364 & 2.8959 & $<.0001$ & 2.8284 & 2.6837 & $<.0001$ \\
$r_{i}$ & -3.0081 & -3.1823 & $<.0001$ & -3.1738 & -3.3755 & $<.0001$ \\
LogSize & 0.0971 & 0.0953 & $<.0001$ & 0.0954 & 0.0824 & $<.0001$ \\
$\beta_{\text {mkt }}$ & 4.6767 & 4.9345 & $<.0001$ & 4.9970 & 5.5545 & $<.0001$ \\
$\beta_{\text {smb }}$ & 0.9444 & 0.9242 & 0.0080 & 0.9816 & 1.0046 & $<.0001$ \\
$\beta_{\text {hml }}$ & 0.8718 & 0.8189 & 0.1136 & 0.6260 & 0.5708 & 0.0544 \\
& 0.2050 & 0.0655 & 0.0137 & 0.1572 & 0.2513 & $<.0001$ \\
\hline & & & & & &
\end{tabular}


Table 2 Summary statistics - macro level variables

This table reports summary statistics for macroeconomic variables for the periods surrounding TRA (JGTRRA) for the full sample (Panel A) and pre- and post- subsamples (Panel B). RREL is the monthly stochastically detrended risk-free rate following Campbell and Shiller (1988), Xrm is the monthly excess market return, $V m$ is the monthly volatility of the excess market return, $G I P$ is the monthly industrial production growth rate, and $C A Y$ is the consumption-wealth ratio. For TRA, the pre-subsample spans 1/31/1995 to 3/31/1997 (firm quarters ended March 1995 through March 1997) and the post-subsample spans 7/1/1997 to 12/31/1998 (firm quarters ended December 1996 through March 1997). For the JGTRRA in 2003, the pre-subsample spans $1 / 1 / 2001$ to $3 / 31 / 2003$ and the post-subsample spans $7 / 1 / 2003$ to $12 / 31 / 2004$.

Panel A: full sample

\begin{tabular}{lrrrrrr}
\hline & & \multicolumn{2}{c}{ TRA } & & JGTRRA & \\
\cline { 3 - 5 } & Mean & Median & Std Dev & Mean & Median & Std Dev \\
\hline RREL & -0.0128 & -0.0259 & 0.0602 & -0.0620 & -0.0415 & 0.0725 \\
Xrm & 0.0480 & 0.1286 & 0.2838 & 0.0162 & 0.0477 & 0.2256 \\
Vm & 3.5385 & 3.4695 & 1.9859 & 4.5356 & 4.2103 & 1.7549 \\
GIP & 0.0079 & 0.0070 & 0.0064 & 0.0010 & 0.0007 & 0.0053 \\
CAY & 0.0144 & 0.0216 & 0.0126 & -0.0068 & -0.0069 & 0.0116 \\
& & & & & & \\
\hline
\end{tabular}

Panel B: pre-vs. post

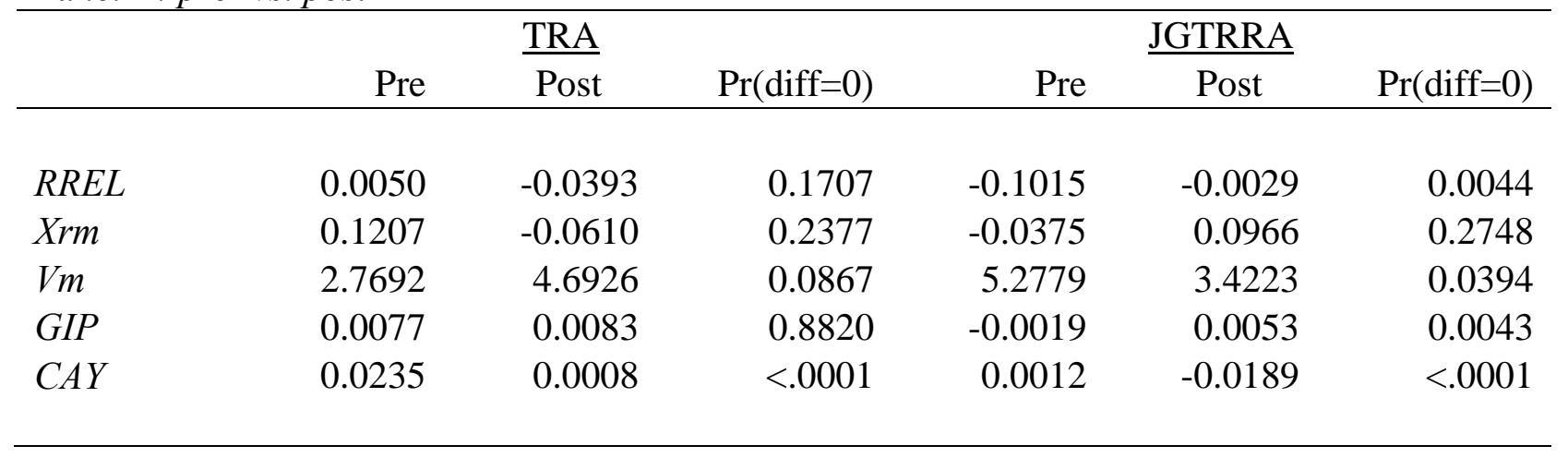


Table 3 Cost of capital — pre vs. post and interaction with financial constraint

Panel A in this table presents the average cost of capital in the quarter immediately before and after the tax cut for TRA (JGTRRA) for high financial constrained (HFC) and low financial constrained (LFC) firms. It contrasts the changes in average cost of capital between high financially constrained and low financially constrained groups. The cost of equity capital estimates are based on Gebhardt, Lee, and Swaminathan (2001), Claus and Thomas (2001), and Gode and Mohanram (2003) for firm $i$ at time $t$. Panel B shows the average cost of capital and the differences in the change of cost of capital for dividendand non-dividend-paying subsamples. $H F C(L F C)$ represents firm-quarters when the predicted financial constraint is above (below) the median financial constraint for the quarter immediately before the tax cut. For TRA, the pre-subsample consists of firm quarter ended in 1997Q1 and the post-subsample consists of firm quarter ended 1997Q3. For the JGTRRA, the pre-subsample consists of firm quarter ended in 2003Q1 and the post-subsample consists of firm quarter ended in 2003Q3. * significant at 10\%, ** significant at $5 \%$ and $* * *$ significant at $1 \%$ level.

Panel A: Whole sample

\begin{tabular}{|c|c|c|c|c|c|c|}
\hline & \multicolumn{3}{|c|}{ TRA } & \multicolumn{3}{|c|}{ JGTRRA } \\
\hline & Pre & Post & Diff (Pre-Post) & Pre & Post & Diff (Pre-Post) \\
\hline & \multicolumn{6}{|c|}{ Average $\left(r_{A V E}\right)$} \\
\hline$H F C$ & 0.1099 & 0.0939 & $0.0160 * * *$ & 0.0988 & 0.0829 & $0.0159 * * *$ \\
\hline$L F C$ & 0.0870 & 0.0781 & $0.0089 * * *$ & 0.0938 & 0.0822 & $0.0116 * * *$ \\
\hline \multirow[t]{2}{*}{ Diff-in-Diff } & & & $0.0072^{* * *}$ & & & $0.0043^{* * *}$ \\
\hline & \multicolumn{6}{|c|}{ Gebhardt-Lee-Swaminathan $\left(r_{G L S}\right)$} \\
\hline$H F C$ & 0.0914 & 0.0792 & $0.0121^{* * *}$ & 0.0955 & 0.0780 & $0.0175^{* * *}$ \\
\hline$L F C$ & 0.0797 & 0.0709 & $0.0089 * * *$ & 0.0933 & 0.0821 & $0.0113^{* * *}$ \\
\hline \multirow[t]{2}{*}{ Diff-in-Diff } & & & $0.0033^{* * *}$ & & & $0.0063^{* * *}$ \\
\hline & \multicolumn{6}{|c|}{$\underline{\text { Claus-Thomas }\left(r_{C T}\right)}$} \\
\hline$H F C$ & 0.1212 & 0.0997 & $0.0216^{* * *}$ & 0.1011 & 0.0791 & $0.0221 * * *$ \\
\hline$L F C$ & 0.0879 & 0.0776 & $0.0102 * * *$ & 0.0920 & 0.0777 & $0.0142^{* * *}$ \\
\hline \multirow[t]{2}{*}{ Diff-in-Diff } & & & $0.0113^{* * *}$ & & & $0.0078^{* * *}$ \\
\hline & \multicolumn{6}{|c|}{$\underline{\text { Gode-Mohanram }\left(r_{G M}\right)}$} \\
\hline$H F C$ & 0.1204 & 0.1030 & $0.0173^{* * *}$ & 0.1013 & 0.0875 & $0.0138^{* * *}$ \\
\hline$L F C$ & 0.0961 & 0.0870 & $0.0091 * * *$ & 0.0988 & 0.0872 & $0.0116 * * *$ \\
\hline Diff-in-Diff & & & $0.0082 * * *$ & & & $0.0022 *$ \\
\hline
\end{tabular}


Panel B: Dividend-paying versus non-dividend-paying subsamples

\begin{tabular}{|c|c|c|c|c|c|c|}
\hline & \multicolumn{3}{|c|}{ TRA } & \multicolumn{3}{|c|}{ JGTRRA } \\
\hline & Pre & Post & Diff (Pre-Post) & Pre & Post & Diff (Pre-Post) \\
\hline & \multicolumn{6}{|c|}{ Dividend-paying firms $\left(r_{\underline{A V E}}\right)$} \\
\hline$H F C$ & 0.1062 & 0.0934 & $0.0128 * * *$ & 0.0952 & 0.0830 & $0.0122 * * *$ \\
\hline$L F C$ & 0.0855 & 0.0772 & $0.0083^{* * *}$ & 0.0933 & 0.0821 & $0.0112^{* * *}$ \\
\hline \multirow[t]{2}{*}{ Diff-in-Diff } & & & $0.0045^{* * *}$ & & & 0.0010 \\
\hline & \multicolumn{6}{|c|}{ Non-dividend paying firms $\left(r_{A V E}\right)$} \\
\hline$H F C$ & 0.1115 & 0.0941 & $0.0174 * * *$ & 0.1006 & 0.0828 & $0.0178 * * *$ \\
\hline$L F C$ & 0.0931 & 0.0819 & $0.0112^{* * *}$ & 0.0953 & 0.0823 & $0.0130 * * *$ \\
\hline Diff-in-Diff & & & $0.0062^{* * *}$ & & & $0.0048^{* * *}$ \\
\hline
\end{tabular}


Table 4 Regression Analysis of the change of cost of equity capital and financial constraint during TRA and JGTRRA

This table reports the panel regression results of the change of cost of equity capital on the probability of financial constraint during TRA and JGTRRA using the following specification:

$$
\begin{aligned}
\hat{r}_{i t}=\alpha & +\beta_{1} \text { Post }_{t}+\beta_{2} F C_{i t-1}+\beta_{3} \text { Post }_{t} \times F C_{i t-1}+\beta_{4} I N S T_{i t-1} \\
& +\beta_{5} \text { Post }_{t} \times I N S T_{i t-1}+\gamma X_{i t}+\varphi Z_{t}+\varepsilon_{i t},
\end{aligned}
$$

where $\hat{r}_{i t}$ is the average of three measures of the cost of equity capital based on Gebhardt, Lee, and Swaminathan (2001), Claus and Thomas (2001), and Gode and Mohanram (2003) for firm i at time $t$, Post is a dummy variable which takes a value of 1 post-tax cut and 0 otherwise, $F C_{i t-1}$ represents the probability of financial constraint faced by firm $i$ at time $t-1, I N S T_{i t-1}$ is firm $i$ 's percentage institutional ownership at time $t-1, X_{i t}$ represents firm level control variables, and $Z_{t}$ represents aggregate variables to control for the overall economic activities. The sample spans 1995Q1 to 1998Q4 for TRA and 2001Q1 to 2004Q4 for JGTRRA. We exclude 1997Q2 and 2003 Q2 to remove possible transient effect. P-values are for two-sided test unless there is predicted sign.

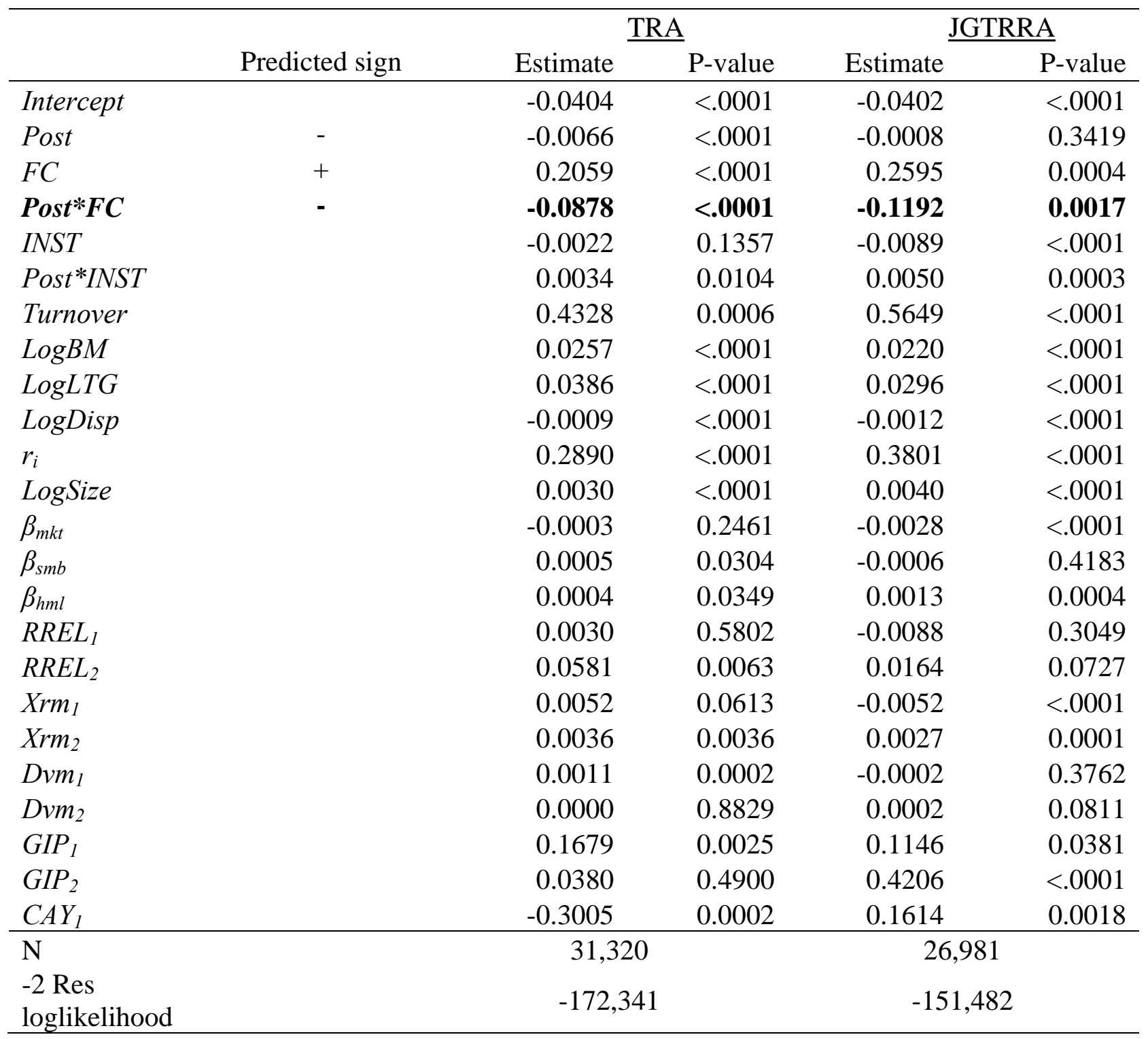


Table 5 Regression Analysis of the Change of Cost of Equity Capital and Financial Constraint for Firms with Different Dividend Policy

This table reports the panel regression results of the change of cost of equity capital and financial constraint for firms with different dividend policy during TRA97 and JGTRRA using the following specification:

$$
\begin{aligned}
\hat{r}_{i t} & =\alpha+\beta_{1} \text { Post }_{t}+\beta_{2} \text { NDiv }_{i t}+\beta_{3} \text { Post }_{t} \times N D i v_{i t}+\beta_{4} F C_{i t-1}+\beta_{5} \text { Post }_{t} \times F C_{i t-1}+\beta_{6} H Y_{i t} \\
& +\beta_{7} \text { Post }_{t} \times H Y_{i t}+\beta_{8} I N S T_{i t-1}+\beta_{9} \text { Post }_{t} \times I N S T_{i t-1}+\gamma X_{i t}+\varphi Z_{t}+\varepsilon_{i t}
\end{aligned}
$$

where $\hat{r}_{i t}$ is the average of three measures of the cost of equity capital based on Gebhardt, Lee, and Swaminathan (2001), Claus and Thomas (2001), and Gode and Mohanram (2003) for firm $i$ at time $t$, Post is a dummy variable which takes a value of 1 post-tax cut and 0 otherwise, NDiv $v_{i t}$ is a dummy variable which takes a value of 1 if firm $i$ is non-dividend paying at time $t$ and 0 otherwise, $H Y_{i t}$ is a dummy variable which takes a value of 1 if firm $i$ 's dividend yield is above the median dividend yield for quarter $t$ and takes a value of 0 otherwise (we calculate dividend yield as four time the dividends declared in the most recent past quarter divided by the end of quarter price as in Naranjo, Nimalendran, and Ryngaert, 1998), $F C_{i t-1}$ represents the probability of financial constraint faced by firm $i$ at time $t-1, I N S T_{i t-1}$ is firm $i$ 's percentage institutional ownership at time $t-1, X_{i t}$ represents firm level control variables, and $Z_{t}$ represents aggregate variables to control for the overall economic activities. The sample spans 1995Q1 to 1998Q4 for TRA and 2001Q1 to 2004Q4 for JGTRRA. We exclude 1997Q2 and 2003Q2 to remove possible transient effect. P-values are for two-sided test unless there is predicted sign. 


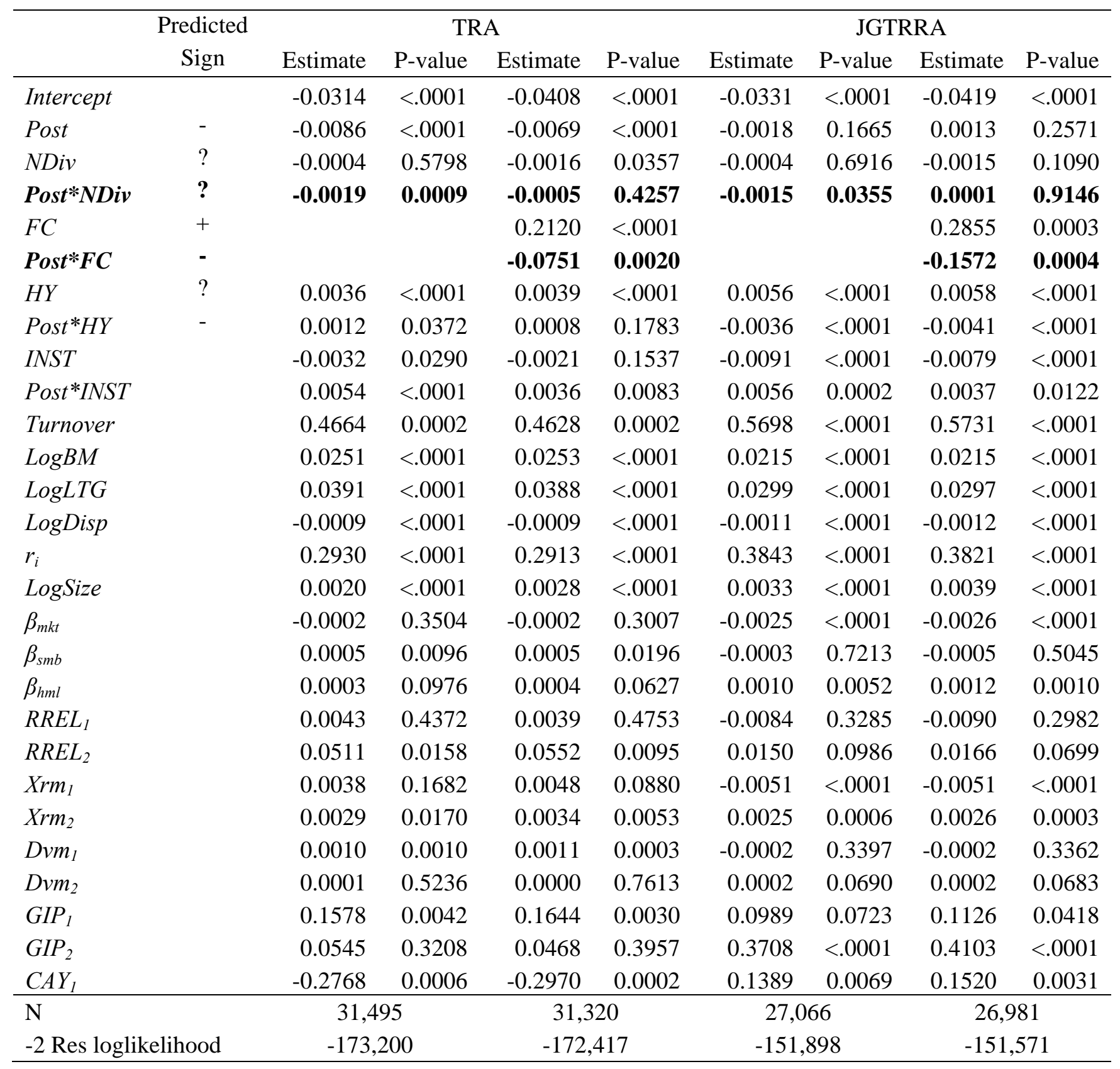


Table 6 Regression Analysis of the Change of Cost of Equity Capital for Financially Constrained Stocks with Different Taxable Individual Investor Ownership

This table reports the panel regression results of the change of cost of equity capital on financially constrained firms with different taxable individual investor ownership during TRA and JGTRRA using the following specification:

$$
\begin{aligned}
\hat{r}_{i t}=\alpha & +\beta_{1} \text { Post }_{t}+\beta_{2} H_{I N D_{i t}} \times L F C_{i t}+\beta_{3} L I N D_{i t} \times H F C_{i t}+\beta_{4} H I N D_{i t} \times H F C_{i t} \\
& +\beta_{5} \text { Post }_{t} \times H I N D_{i t} \times L F C_{i t}+\beta_{6} \text { Post }_{t} \times L I N D_{i t} \times H F C_{i t} \\
& +\beta_{7} \text { Post }_{t} \times H I N D_{i t} \times H F C_{i t}+\gamma X_{i t}+\varphi Z_{t}+\varepsilon_{i t},
\end{aligned}
$$

where $\hat{r}_{i t}$ is the average of three measures of the cost of equity capital based on Gebhardt, Lee, and Swaminathan (2001), Claus and Thomas (2001), and Gode and Mohanram (2003) for firm $i$ at time $t$, Post is a dummy variable which takes a value of 1 post-tax cut and 0 otherwise, $H I N D_{i t}$ $\left(L I N D_{i t}\right)$ is a dummy variable which takes a value of 1 if firm $i$ 's individual investor ownership at time period $t$ is above (below) the median individual investor ownership for all firms at period $t, H F C_{i t}\left(L F C_{i t}\right)$ is a dummy variable that takes a value of 1 if the probability of financial constraint is above (below) the firms' median probability of financial constraint at quarter $t$ and takes a value of 0 otherwise, $X_{i t}$ represents firm level control variables, and $Z_{t}$ represents aggregate variables to control for the overall economic activities. The sample spans 1995Q1 to 1998Q4 for TRA and 2001Q1 to 2004Q4 for JGTRRA. We exclude 1997Q2 and 2003Q2 to remove possible transient effect. P-values are for two-sided test unless there is predicted sign. 


\begin{tabular}{|c|c|c|c|c|c|}
\hline & \multirow{2}{*}{$\begin{array}{c}\text { Predicted } \\
\text { Sign } \\
\end{array}$} & \multicolumn{2}{|c|}{ TRA } & \multicolumn{2}{|c|}{ JGTRRA } \\
\hline & & Estimate & P-value & Estimate & P-value \\
\hline Intercept & & -0.0365 & $<.0001$ & -0.0387 & $<.0001$ \\
\hline Post & - & -0.0066 & $<.0001$ & 0.0010 & 0.2787 \\
\hline$H I N D * L F C$ & ? & 0.0016 & 0.0170 & 0.0015 & 0.0893 \\
\hline$L I N D * H F C$ & $?$ & 0.0034 & $<.0001$ & 0.0027 & 0.0071 \\
\hline$H I N D * H F C$ & ? & 0.0053 & $<.0001$ & 0.0062 & 0.0004 \\
\hline Post ${ }^{*} H I N D * L F C$ & - & -0.0009 & 0.1461 & 0.0001 & 0.4361 \\
\hline Post*LIND*HFC & - & -0.0028 & 0.0002 & -0.0031 & 0.0016 \\
\hline Post ${ }^{*}$ HIND ${ }^{*}$ HFC & - & -0.0039 & 0.0006 & -0.0057 & 0.0015 \\
\hline Turnover & & 0.4694 & 0.0001 & 0.4771 & $<.0001$ \\
\hline $\log B M$ & & 0.0253 & $<.0001$ & 0.0217 & $<.0001$ \\
\hline $\log L T G$ & & 0.0389 & $<.0001$ & 0.0296 & $<.0001$ \\
\hline LogDisp & & -0.0009 & $<.0001$ & -0.0010 & $<.0001$ \\
\hline$r_{i}$ & & 0.2931 & $<.0001$ & 0.3864 & $<.0001$ \\
\hline LogSize & & 0.0026 & $<.0001$ & 0.0036 & $<.0001$ \\
\hline$\beta_{m k t}$ & & -0.0002 & 0.2856 & -0.0027 & $<.0001$ \\
\hline$\beta_{\text {smb }}$ & & 0.0005 & 0.0213 & -0.0003 & 0.6833 \\
\hline$\beta_{h m l}$ & & 0.0004 & 0.0460 & 0.0010 & 0.0046 \\
\hline$R R E L_{1}$ & & 0.0034 & 0.5288 & -0.0071 & 0.3923 \\
\hline$R R E L_{2}$ & & 0.0625 & 0.0029 & 0.0122 & 0.1730 \\
\hline $\mathrm{Xrm}_{1}$ & & 0.0056 & 0.0449 & -0.0051 & $<.0001$ \\
\hline $\mathrm{Xrm}_{2}$ & & 0.0037 & 0.0021 & 0.0028 & $<.0001$ \\
\hline$D v m_{1}$ & & 0.0012 & $<.0001$ & -0.0002 & 0.4001 \\
\hline $\mathrm{Dvm}_{2}$ & & 0.0000 & 0.9120 & 0.0002 & 0.0753 \\
\hline$G I P_{1}$ & & 0.1852 & 0.0007 & 0.1101 & 0.0432 \\
\hline$G I P_{2}$ & & 0.0352 & 0.5194 & 0.3585 & $<.0001$ \\
\hline$C A Y_{1}$ & & -0.3265 & $<.0001$ & 0.1547 & 0.0021 \\
\hline $\mathrm{N}$ & & 31 , & & 27 & \\
\hline -2 Res loglikelihood & & -174 & & -15 & \\
\hline
\end{tabular}


Table 7 Robustness Analysis on the Changes of Cost of Equity of Financially Constrained Firms during TRA and JGTRRA

This table reports the robustness analysis of the panel regression estimation using an alternative measure of the probability of financial constraint for firms based only on firm size and age ( $S A$ Index) as in Hadlock and Pierce (2010). Specifically, columns (1) and (2) show the base case results of the change of cost of equity capital on the probability of financial constraint for both TRA and JGTRRA; columns (3) reports the results of the change of cost of equity capital for firms with different dividend policy with and without financial constraint measure for JGTRRA; columns (4) and (5) provide the results of the change of cost of equity capital on financially constrained firms with different taxable individual investor ownership during TRA and JGTRRA.

The dependent variable $\hat{r}_{i t}$ is the average of three measures of the cost of equity capital based on Gebhardt, Lee, and Swaminathan (2001), Claus and Thomas (2001), and Gode and Mohanram (2003) for firm i at time $t$, Post is a dummy variable which takes a value of 1 post-tax cut and 0 otherwise, $F C_{i t}$ represents the probability of financial constraint faced by firm $i$ at time $t, I N S T_{i t-1}$ is firm $i$ 's percentage institutional ownership at time $t-1, N D i v_{i t}$ is dummy variable which takes a value of 1 if firm $i$ is non-dividend paying at time $t$ and 0 otherwise, $H F C_{i t}\left(L F C_{i t}\right)$ is a dummy variable which takes a value of 1 if the probability of financial constraint faced by firm $i$ at time $t$ is above (below) the median probability of financial constraint for all stocks at time $t$ and takes a value 0 otherwise, $H Y_{i t}$ is a dummy variable which takes a value of 1 if firm $i$ 's dividend yield is above (below) the median dividend yield for quarter $t$ and takes a value of 0 otherwise, $H I N D_{i t}$ $\left(L I N D_{i t}\right)$ is a dummy variable which takes a value of 1 if firm $i$ 's individual investor ownership at time period $t$ is above (below) the median individual investor ownership for all firms at period $t, X_{i t}$ represents firm level control variables, and $Z_{t}$ represents aggregate variables to control for the overall economic activities. The sample spans 1995Q1 to 1998Q4 for TRA and 2001Q1 to 2004Q4 for JGTRRA. We exclude 1997Q2 and 2003Q2 to remove possible transient effect. 
Post

NDiv

Post*NDiv

SAIndex

Post*SAIndex

$H Y$

Post*HY

INST

Post*INST

$H I N D^{*} L F C$

LIND*HFC

$H I N D * H F C$

Post ${ }^{*} H I N D^{*} L F C$

Post*LIND*HFC

Post*HIND*HFC
Predicted TRA JGTRRA TRA JGTRRA TRA JGTRRA sign

(1) (2)

(3)

(4)

(5)

(6) $\begin{array}{lll}-0.0071 & -0.0005 & -0.0077\end{array}$ $<.0001$

?

0.8010

$<.0001$

$-0.0013$

0.1003

$-0.0011$

0.0918

0.0023

0.2627

$-0.0021$

0.0242

0.0004

0.6541

$+$

0.2184

$<.0001$

0.4468

0.2288

$<.0001<.0001$

0.5124

$<.0001$

$-0.0574$

$\mathbf{- 0 . 1 1 3 4}-\mathbf{0 . 0 2 8 6}$

$-0.1763$

0.0071

0.0034

0.261

$<.0001$

$0.0038 \quad 0.0061$

$<.0001<.0001$

$0.0007-0.0042$

$0.2140<.0001$

$\begin{array}{llll}-0.0021 & -0.0081 & -0.0021 & -0.0068\end{array}$

$\begin{array}{llll}0.1598 & <.0001 & 0.1637 & <.0001\end{array}$

0.0039

0.0050

0.0044

0.0033

0.0021

0.0003

0.0265

$\begin{array}{rr}0.0028 & 0.0013 \\ 0.0007 & 0.1870 \\ 0.0031 & 0.0040 \\ <.0001 & <.0001 \\ 0.0041 & 0.0072 \\ <.0001 & <.0001 \\ -0.0011 & 0.0002 \\ 0.2724 & 0.8216 \\ \mathbf{- 0 . 0 0 2 5} & \mathbf{- 0 . 0 0 1 9} \\ \mathbf{0 . 0 0 0 3} & \mathbf{0 . 0 2 3 6} \\ \mathbf{- 0 . 0 0 3 5} & \mathbf{- 0 . 0 0 4 0} \\ \mathbf{0 . 0 0 2 0} & \mathbf{0 . 0 0 6 2}\end{array}$

